
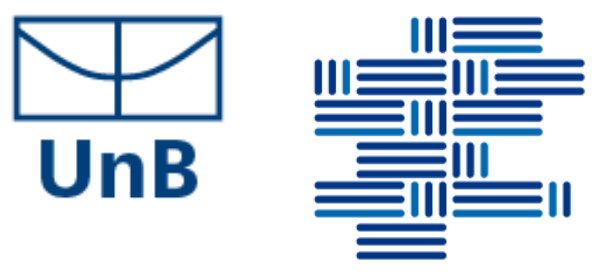

ESPECIALIZACT̃̃O EM

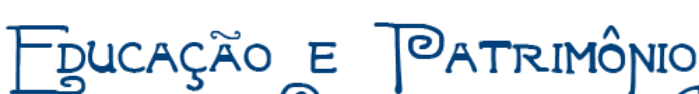

Cultural e flrtístico

LÍGIA MELO DOS SANTOS

A ARQUITETURA DE ONTEM E DE HOJE EM CATAGUASES (MG): REFLEXÕES SOBRE A SIMULTANEIDADE DE ESTILOS

Brasília - DF

2019

LÍGIA MELO DOS SANTOS 


\section{A ARQUITETURA DE ONTEM E DE HOJE EM CATAGUASES (MG): REFLEXÕES SOBRE A SIMULTANEIDADE DE ESTILOS}

Trabalho de Conclusão do Curso de Especialização em Educação e Patrimônio Cultural e Artístico, lato sensu - a distância, do Programa de Pós-graduação em Arte-PPG-Arte, Instituto de Artes da Universidade de Brasília.

Orientador: Prof. Antenor Ferreira Corrêa.

Brasília - DF

2019 


\section{AGRADECIMENTOS}

Agradeço em especial a toda equipe e coordenação do curso de Educação e Patrimônio Cultural e Artístico, e pela oportunidade de estar participando do curso e apresentando este trabalho mesmo na dificuldade da gravidez.

Agradeço ao meu esposo, que também faz parte da equipe do curso, Elias Filho, pelo apoio e paciência ajudando na elaboração desta pesquisa e nos trabalhos durante o curso.

Agradeço as pessoas que me atenderam na cidade de Cataguases e forneceram informações valiosas das quais pude inserir nesta pesquisa.

Agradeço ao Professor Antenor Ferreira pelas dicas, mesmo na dificuldade de escrita, e por todos que de certa forma ajudaram na elaboração desta pesquisa. 


\section{SUMÁRIO}

RESUMO.

1. INTRODUÇÃO

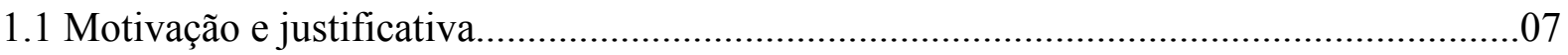

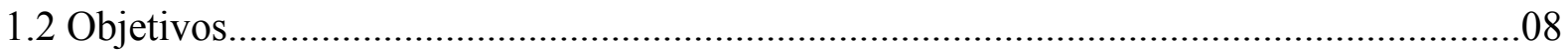

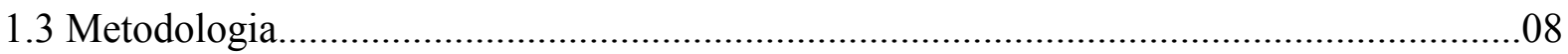

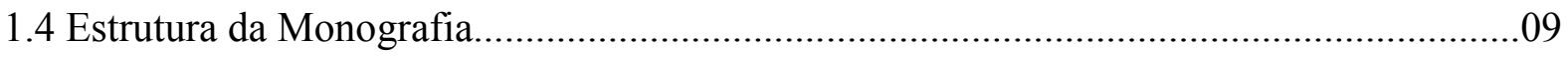

2. HISTÓRIA DE CATAGUASES - MG..................................................................... 10

3. RELATOS DA VIAGEM REALIZADA EM CATAGUASES - MG.............................12

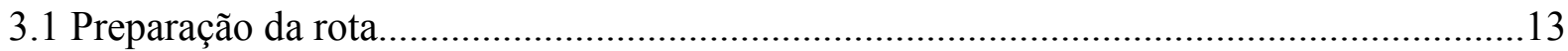

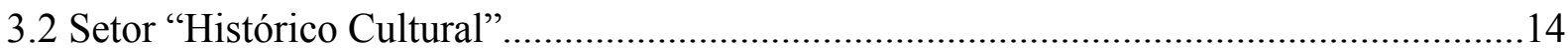

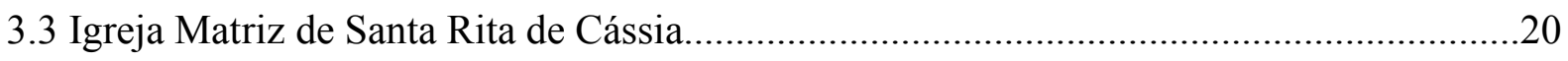

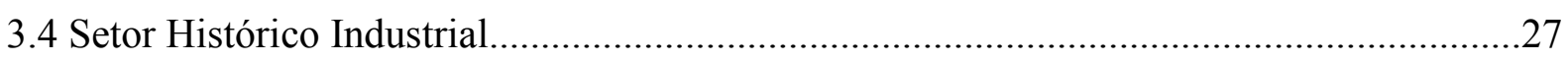

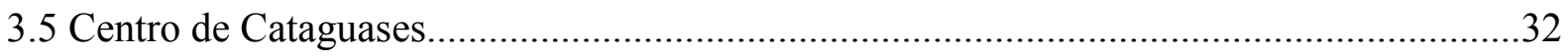

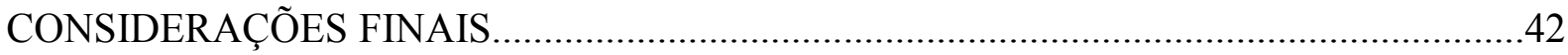

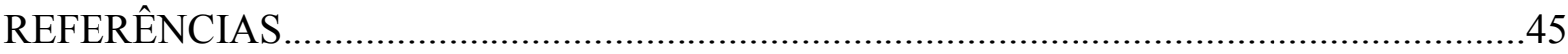




\section{LISTA DE IMAGENS}

Imagem 1 - Mapa em elaboração da trajetória da pesquisa de Cataguases.................................... 12

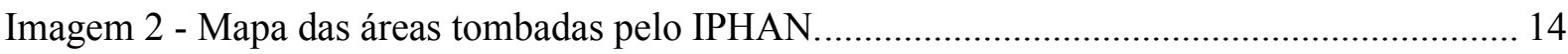

Imagem 3 - Entrada do Restaurante Girassol............................................................................... 15

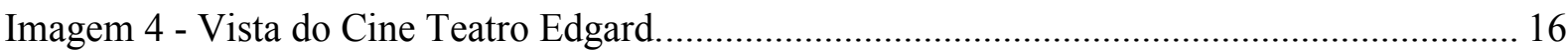

Imagem 5 - Concha Acústica da Praça Manoel Inácio Peixoto. ..................................................... 17

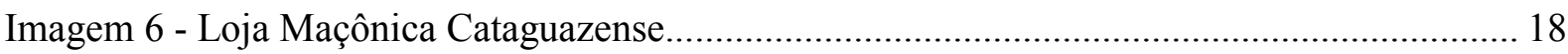

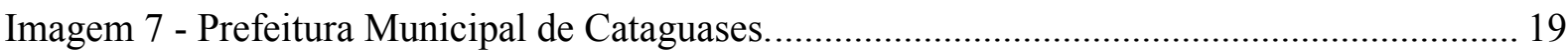

Imagem 8 - Sala de Reuniões da Prefeitura Municipal de Cataguases. .......................................... 20

Imagem 9 - Vista da Igreja Matriz de Santa Rita de Cássia............................................................ 21

Imagem 10 - Capela da Igreja Santa Rita de Cássia.................................................................... 22

Imagem 11 - Interior da Igreja de Santa Rita de Cássia............................................................... 23

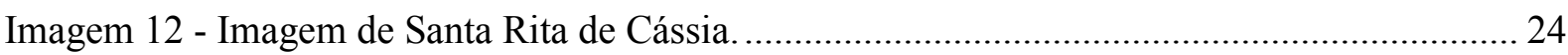

Imagem 13 - Escadaria que leva ao sino na Igreja Santa Rita de Cássia. .................................... 25

Imagem 14 - Planta Baixa da Igreja de Santa Rita de Cássia....................................................... 26

Imagem 15 - Pintura na saída da Igreja de Santa Rita de Cássia. ................................................. 27

Imagem 16 - Ponte Metálica sobre o Rio Pomba............................................................................ 28

Imagem 17 - Antigo Edifício da Polícia Civil de Cataguases........................................................ 29

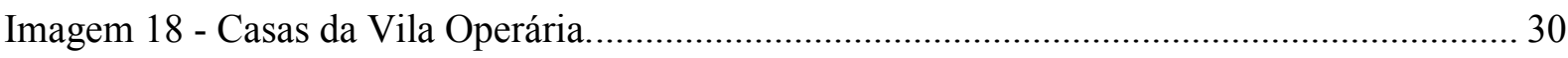

Imagem 19 - Ponte de Concreto com vista para a Ponte Metálica................................................. 31

Imagem 20 - Sindicato dos Trabalhadores da Indústria de Energia Elétrica de Cataguases.......... 32

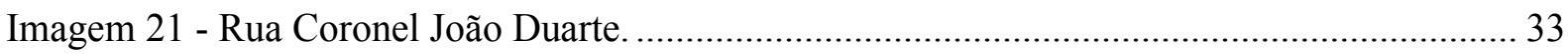

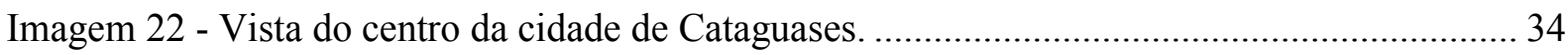

Imagem 23 - Biblioteca Municipal de Cataguases Ascânio Lopes. .................................................. 35

Imagem 24 - Estação Ferroviária de Cataguases........................................................................ 36

Imagem 25 - Quadros localizados na entrada da sede do IPHAN em Cataguases......................... 37

Imagem 26 - Interior do Hotel Casarão em Pirenópolis-GO.......................................................... 38

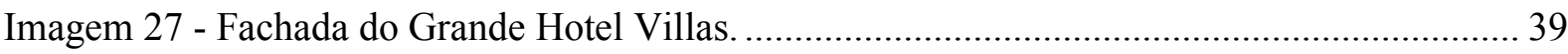

Imagem 28 - Lateral do Shopping Bahamas, antiga Fábrica de Fiação e Tecelagem.................... 40

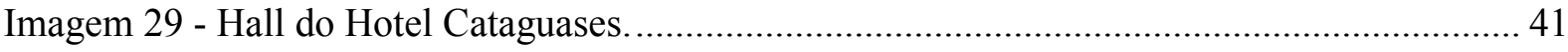

Imagem 30 - Planejamento Final do trajeto da pesquisa em Cataguases...................................... 43

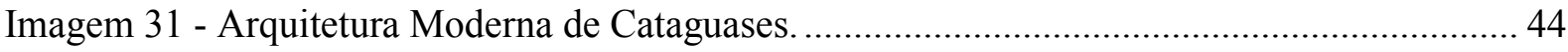

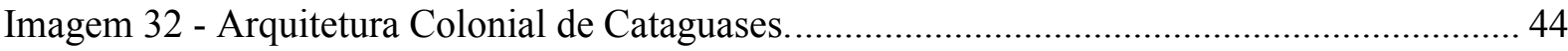




\section{RESUMO}

A presente pesquisa tem como objetivo geral compreender o processo histórico/arquitetônico ocorrido na cidade de Cataguases - MG desde os anos 40 até os dias de hoje no que se refere aos edifícios tombados. As impressões dar-se-ão na forma de relatos pessoais escritos após pesquisa de campo para verificar como está a cidade atualmente. Os objetivos específicos desta pesquisa constituem-se em refletir sobre a simultaneidade de estilos que convivem nos projetos arquitetônicos, nas obras artísticas e nas fotografias da arquitetura da cidade. Assim, serão realizadas análises de projetos de arquitetura da cidade visando um melhor entendimento do processo de Patrimônio Cultural da região. A metodologia utilizada para a pesquisa foi o estudo de caso, que agiu como principal ferramenta a pesquisa de campo. A visita à Cataguases foi determinante para averiguar o estado de conservação das obras arquitetônicas já tombadas e também daquelas não tombadas, o que tornou possível uma análise mais íntima acerca do Patrimônio Histórico e Cultural da cidade. Além disso, somente com a pesquisa de campo pode se ter ideia do que é estar de frente a edifícios tão distintos entre si e perceber como estes interferem no dia a dia da composição da cidade. Dessa forma, o trabalho se apresenta como um apanhado de percepções pessoais sobre os aspectos arquitetônicos da cidade, complementado com diversas imagens autorais realizadas ao longo da viagem.

Palavras-chave: Cataguases; Obras Arquitetônicas; Estilos Arquitetônicos; Patrimônio Histórico e Artístico. 


\section{INTRODUÇÃO}

O patrimônio cultural e artístico é a memória de um povo, de um lugar. Então, patrimônio é aquilo que representa algo para uma comunidade, é algo que tem uma identidade cultural (FUNARI \& PINSKY, 2003). A palavra patrimônio refere-se também a uma escolha oficial de determinados bens para representar o passado histórico e cultural de uma sociedade. A escolha de determinado patrimônio como símbolo nacional, regional ou local é feita por órgãos oficiais de preservação, no caso de Cataguases, o Departamento Municipal do Patrimônio Histórico e Artístico de Cataguases (DEMPHAC), a nível Municipal, o Instituto Estadual de Patrimônio Histórico e Artístico de Minas Gerais (IEPHA/MG), a nível estadual e o IPHAN (Instituto do Patrimônio Histórico e Artístico Nacional), a nível nacional.

Conforme a Constituição Federal de 1988 é dever de todo cidadão cuidar do patrimônio cultural do país. No âmbito governamental, essa tarefa aparece como competência comum da União, dos Estados, do Distrito Federal e dos Municípios, responsáveis pela proteção de documentos, obras e outros bens considerados de valor histórico, artístico e cultural, além de paisagens naturais notáveis e sítios arqueológicos.

\subsection{Motivação e justificativa}

O município de Cataguases, localizado no estado de Minas Gerais, a partir de 1985, vem se preocupando em legislar sobre a proteção do patrimônio histórico municipal, desde então existem várias leis municipais visando à proteção do patrimônio. Segundo dados do Instituto Brasileiro de Geografia e Estatística (IBGE, 2009), Cataguases possui uma população estimada em 70.507 habitantes. É um dos municípios que compõe a Microrregião da Zona da Mata de Minas Gerais, tendo como base uma economia tradicionalmente apoiada na atividade agropecuária que alimenta importantes indústrias, a criação de gado leiteiro e plantações de cana-de-açúcar, café, milho e feijão.

Segundo o Processo de Tombamento de Cataguases (1994), a palavra Cataguases é de origem indígena. A tradução mais aceita é a traduzida por gente boa, cuja forma original julga-se ser catu-auá. Em virtude a esse Processo de Tombamento da cidade de Cataguases MG, percebo a ausência de materiais científicos de como se encontra a situação da 
Arquitetura existente da cidade e até mesmo da catalogação da parte arquitetônica já tombada como Patrimônio Cultural e Artístico.

Meu interesse pela cidade de Cataguases se dá pela quantidade e qualidade do patrimônio existente no local, pois por lá já se passaram muitos arquitetos e artistas importantes. Além disso, em Cataguases não se encontram apenas construções modernas, mas também obras coloniais que dão um contraste de estilos bem interessante e notável à cidade. Assim, justifico a importância dessa pesquisa no sentido de compreender, catalogar, comparar e registrar em fotos, relato autobibliográfico e projetos arquitetônicos o desenvolvimento da cidade de Cataguases - MG, desde a década de 40 até os dias de hoje, entendendo esse contexto também por um olhar dos habitantes locais da cidade, e de relatos já existentes nos mais diversos locais tombados como Patrimônio Histórico e Cultural da cidade.

\subsection{Objetivos}

O objetivo geral desta pesquisa envolve a compreensão do processo histórico/arquitetônico ocorrido na cidade de Cataguases - MG desde os anos 40 até os dias de hoje, em forma de relatos pessoais de como está a cidade atualmente.

Já os objetivos específicos desta pesquisa constituem-se em refletir sobre a simultaneidade de estilos que convivem nos projetos arquitetônicos, nas obras artísticas e nas fotografias da arquitetura da cidade de Cataguases - MG e; realizar análises de projetos de arquitetura da cidade de Cataguases - MG para melhor entendimento do processo de Patrimônio Cultural da região.

\subsection{Metodologia}

Quanto à parte metodológica da pesquisa, a forma de trabalho escolhida é o estudo de caso. De acordo com Gil, o estudo de caso não aceita um roteiro rígido para a sua delimitação, mas é possível definir quatro fases que demonstram o seu desenvolvimento: delimitação da unidade-caso; coleta de dados; seleção, análise e interpretação dos dados; elaboração do relatório (GIL, 1995). Dessa forma, escolhi realizar relatórios e diários de bordo produzidos durante uma viagem de cinco dias à cidade de Cataguases em junho de 2018. Assim, fiz uma análise e comparei com materiais já produzidos sobre a história e a arquitetura da cidade. 
Importante notar que todas as imagens existentes nesta pesquisa foram fotografadas pela autora, via câmera do celular. As imagens no interior dos lugares tiveram autorização para a disponibilidade dessas imagens.

\subsection{Estrutura da Monografia}

Esta monografia está dividida em cinco partes: introdução, a história de Cataguases, relato da viagem realizada em Cataguases, considerações finais e referências.

A parte 1 intitulada "Introdução" apresenta o tema, que está centrado no termo "patrimônio cultural e artístico". Além disso, expõe a motivação e a justificativa pela escolha do tema, os objetivos, a metodologia e, por fim, a estrutura da monografia em si.

A parte 2 "História de Cataguases - MG" faz um breve relato da história sobre a cidade em estudo. Com esse relato pretende-se explicar um pouco mais do processo histórico pelo qual passou Cataguases, de forma a se trazer esse tema (do patrimônio de Cataguases) para um estudo mais aprofundado.

A parte 3 "Relato da viagem realizada em Cataguases" demonstra como foi feito o processo do trabalho por meio da metodologia "estudo de caso". Aqui é possível entender que a pesquisa foi feita através de um estudo e um roteiro previamente estabelecido que possibilitasse uma visita à cidade em estudo. Após essa viagem, no decorrer da elaboração do trabalho, foi necessário dividir a visitação em quatro momentos, de forma a decompor a cidade em setores e facilitar o desenvolvimento da pesquisa, são eles: o setor histórico cultural, a Igreja Matriz de Santa Rita de Cássia, o setor histórico industrial e o centro de Cataguases.

Nas "Considerações Finais" apresento minhas impressões sobre o material e análises realizadas ao longo deste estudo, além e de minhas apreciações finais com relação à cidade de Cataguases. Busquei, nesta penúltima parte, relatar aquilo que senti ao final da viagem e do trabalho de pesquisa como um todo.

Por fim, a monografia termina com as referências utilizadas ao longo da pesquisa. Estas, no entanto, serviram mais como uma base para o meu trabalho, já que a produção do mesmo se baseou principalmente em minha experiência pessoal durante a viagem à Cataguases. 


\section{HISTÓRIA DE CATAGUASES - MG}

Em 1943, Chico Peixoto encomenda ao arquiteto Oscar Niemeyer o projeto de sua residência em Cataguases. No mesmo momento era concluída a obra do edifício do Ministério da Educação e Saúde, atual Palácio Gustavo Capanema, no Rio de Janeiro, obra em que Niemeyer ajudou a projetar, e Juscelino Kubitschek também encomendava ao mesmo arquiteto o conjunto da Pampulha. Três anos mais tarde, sob o pedido do próprio Chico Peixoto, Niemeyer desenvolve o projeto do Colégio Cataguases (SANTOS \& LAGE, 2005, p. 17). A concentração de poderes econômico e político nas mãos de um mesmo grupo familiar, por sua vez comprometido com as ideias vanguardistas e com o movimento moderno, criou, neste momento, as condições para a transformação do espaço físico da cidade (SANTOS \& LAGE, 2005, p. 32). Essa ideia retrata exatamente a importância e relevância dessa pesquisa, como foi descrito no final do capítulo anterior.

Santos e Lage, ainda descrevem que desde então, a cidade não parou mais de receber projetos de arquitetos como Carlos Leão, Bolonha, Aldary Toledo, os irmãos "Roberto", Gilberto Lemos, Luzimar Telles, assim como paisagistas como Burle Marx, Carlos Percy, também projetos de mobiliário de Joaquim Tenreiro e obras de arte de Portiniari, Di Cavalcanti, Djanira, Iberê Camargo, Emeric Marcier, Jan Zach e Bruno Giorgi, e outros. Até final da década de 50, Cataguases se tornou palco desses artistas, criando assim um ambiente na cidade em que, ao mesmo tempo em que havia o convívio da população em geral com a modernidade através de projetos públicos, a burguesia se interessava em adquirir acervos modernos propiciando o surgimento de coleções.

No ano de 1995, o Conselho do Instituto do Patrimônio Histórico e Artístico Nacional - IPHAN, acatando parecer do conselheiro relator, arquiteto Ítalo Campo, por sua vez contando com o apoio do Processo de Tombamento proposto e instruído pela representação do IPHAN 13 ${ }^{\mathrm{a}}$ (Coordenação Regional em Minas Gerais), decidiu pelo tombamento de uma poligonal no centro da cidade de Cataguases, considerando sua importância para a cultura nacional.

De acordo com o referido processo, o patrimônio cultural de Cataguases, que sem dúvida transcende os limites municipais e estaduais, já identificado e documentado, recebe a proteção federal, através da sua inscrição no Livro do Tombo Histórico, das Belas Artes, das Artes Aplicadas, bem como no Livro do Tombo Arqueológico, Etnográfico e Paisagístico, 
além da necessária promoção dispensada ao patrimônio cultural brasileiro, conforme parecer do arquiteto Antônio Luiz Dias de Andrade.

$\mathrm{Na}$ história de Cataguases, portanto, destacam-se os efeitos que a prosperidade econômica, alcançada, primeiramente, pela produção cafeeira e pela chegada da ferrovia e, posteriormente, pela industrialização, tiveram sobre a cultura local. A história de Cataguases cresceu junto com o Modernismo, e a revolução que a arquitetura da época proporcionou na cidade e nas cidades vizinhas, inclusive na capital Rio de Janeiro. Pode se dizer que no início do século XX, a facilidade de comunicação com a capital do país, o Rio de Janeiro, proporcionada pela ferrovia, juntamente com a formação de uma elite econômica e intelectual, foram fatores facilitadores para o desenvolvimento de um cenário propício às artes, principalmente, aquelas ligadas ao movimento modernista, pelo qual Cataguases é conhecida nacionalmente. Os cenários de grandes artistas e arquitetos podem ser vistos até os dias de hoje (2018), no qual, o patrimônio cultural e os tombamentos realizados na cidade favoreceram e sempre irão favorecer para a conservação de várias obras artísticas e arquitetônicas. 


\section{RELATOS DA VIAGEM REALIZADA EM CATAGUASES - MG}

O primeiro feito antes de embarcar para o Rio de Janeiro, rumo a Cataguases ${ }^{1}$, foi a realização de um mapa pelo aplicativo Google Maps. O traçado das rotas no mapa seguiu baseado em dois princípios: os monumentos tombados pelo IPHAN, de acordo com o Guia da Arquitetura Modernista Oficial de Cataguases de 2012 (2 $2^{\text {a }}$ Edição), e os lugares e regiões onde há situações históricas, porém não fazem parte do tombamento, ou são recentes em relação a modernidade da cidade. Outra questão, este Guia só apresenta de fato as obras modernistas, deixando de lado alguns edifícios importantes para Cataguases que fazem parte de outras épocas. Na imagem abaixo está a imagem do mapa, com os traçados que foram realizados durante a exploração de cinco dias de viagem dedicados a esta pesquisa.

Imagem 1 - Mapa em elaboração da trajetória da pesquisa de Cataguases.

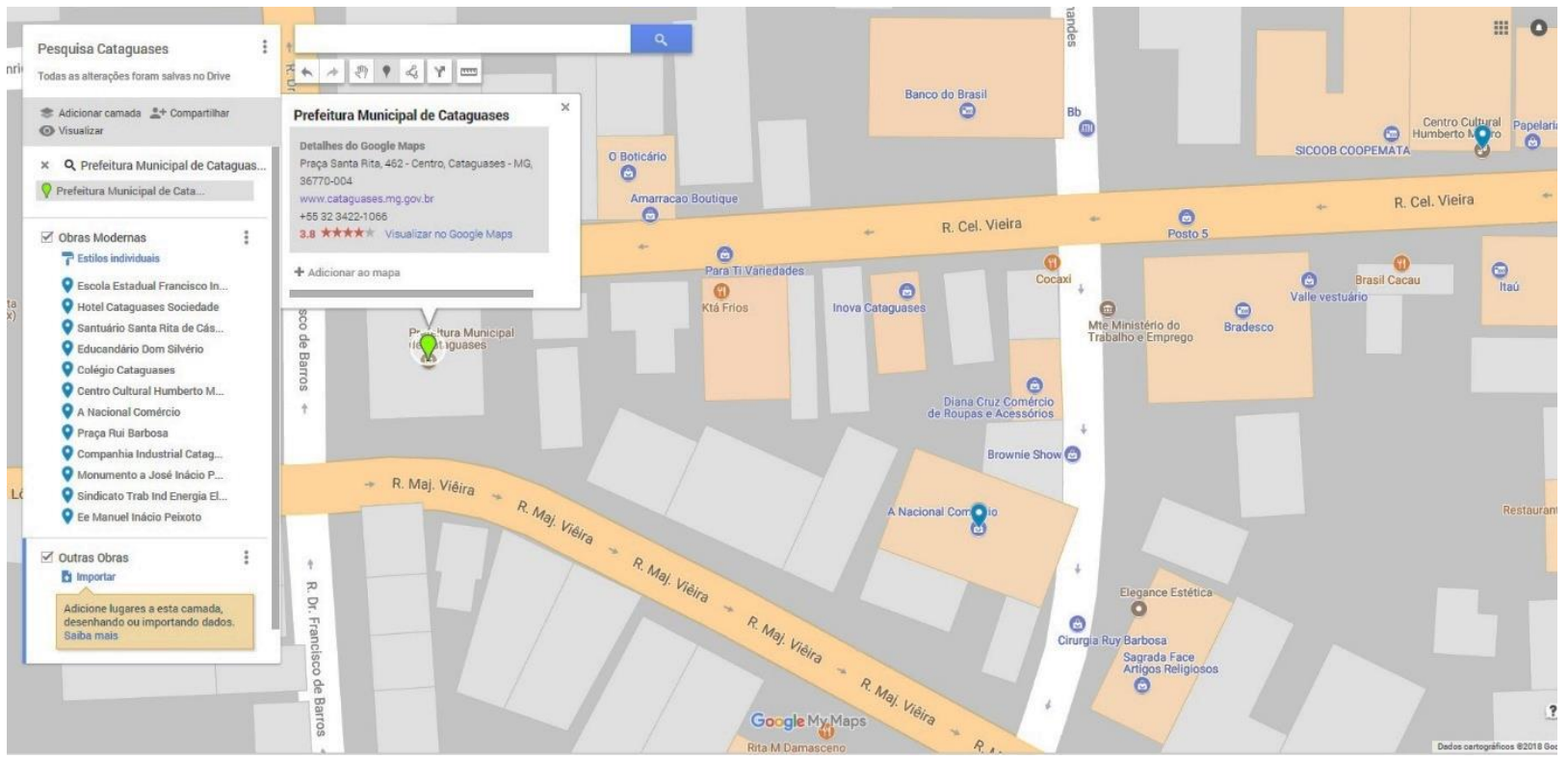

Fonte: Google Maps

A área que aparece na imagem anterior compreende cerca de $90 \%$ da área tombada pelo IPHAN, faltando quatro localizações e regiões que estão mais afastadas do centro da cidade. Com esse planejamento de rotas, foi possível ter uma ideia do entendimento de cada setor estratégico da cidade, que separo aqui como: Cultural, Empresarial, Artístico, Governamental (prefeitura e afins) e o Arquitetônico. Andando pela cidade é visível identificar cada setor. Atualmente, percebi que o aglomerado de favelas em torno do centro

${ }^{1} \mathrm{O}$ Rio de Janeiro é a rota mais rápida para chegar à cidade, e que pode ser vista na imagem $\mathrm{X}$, que compara as rotas de cada cidade e também considerado a saída da cidade de Brasília. 
cresceu muito, e em conversa com alguns moradores e comerciantes, chego a conclusão de que o centro de Cataguases virou um ponto de encontro para esses moradores. Os principais pontos de encontro da cidade se resumem na praça principal, onde se encontra grande parte dos monumentos tombados pelo IPHAN e a igreja, que aos finais de semana concentra grande partes dos fiéis, tanto na missa, como após a missa, em frente à igreja, com atrações para crianças e adultos, como parquinho e diversas opções de comida.

Ao chegar na cidade, a primeira parada é a rodoviária. Essa que tem os destinos principais as cidades de Petrópolis - RJ, Além Paraíba - RJ e o Rio de Janeiro - RJ, com muitos horários disponíveis para essas localidades. Para outras localidades, as opções são mais restritas. As opções de hotéis na cidade atendem a todos os turistas, a maior parte desses hotéis funciona 24 horas e estão localizados no centro, estrategicamente próximos aos monumentos tombados.

\subsection{Preparação da rota}

O primeiro momento do primeiro dia foi localizar onde fica cada região, e quais os monumentos tombados. Para isso, utilizei como referência o Guia de Cataguases, o qual é citado anteriormente em outros trechos dessa pesquisa. É possível visualizar esse mapa na imagem abaixo. 
Imagem 2 - Mapa das áreas tombadas pelo IPHAN.
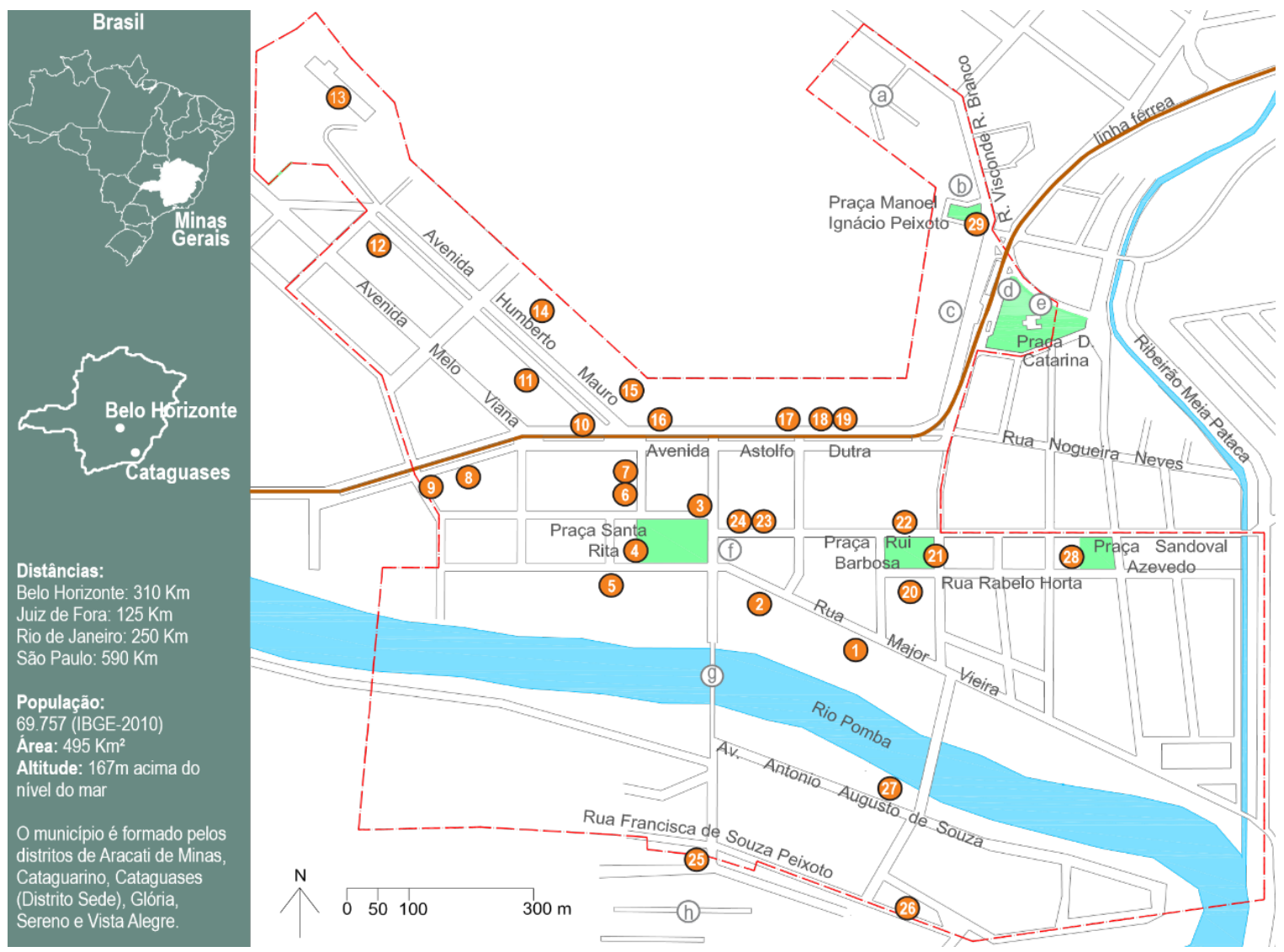

Fonte: (ALONSO, 2012, p. 32)

No mapa da imagem 2, se resume praticamente todo o caminho traçado para realização da pesquisa, exceto um deles, que será abordado mais adiante, que se refere a um monumento que não foi tombado pelo IPHAN.

Como o hotel onde hospedei fica ao lado da rodoviária, nosso trajeto seguirá por uma ordem de contemplação e atrativos da cidade de acordo com o dia e o clima. Um dos pontos mais importantes da cidade é a Praça Rui Barbosa.

\subsection{Setor "Histórico Cultural"}

A Praça Rui Barbosa possui seus traços modernistas em seu piso de ladrilhos hidráulicos e pedras portuguesas, em seus bancos curvos e extensos revestidos por pastilhas e também no design inovador da concha acústica. Porém seu projeto original ainda foi modificado pela supressão de alguns jardins e substituição da iluminação. 
Ao redor da praça, é possível ver a construção de prédios e casas que diferem da arquitetura dos anos 50, sendo que algumas obras foram tombadas e outras apenas encontramse conservadas. A beleza do local hoje é tomada por diversos pontos que o deixam, em minha opinião, sem forma e sem parte de seu caráter principal. Hoje, a praça é tomada de vendedores ambulantes e feirantes, principalmente nos dias de domingo. De acordo com os moradores e lojistas, esse comportamento cresceu muito há cerca de 10 anos. $\mathrm{O}$ único comércio que mantém a identidade e característica colonial da cidade é o Restaurante Girassol, localizado nas redondezas da praça.

Imagem 3 - Entrada do Restaurante Girassol.

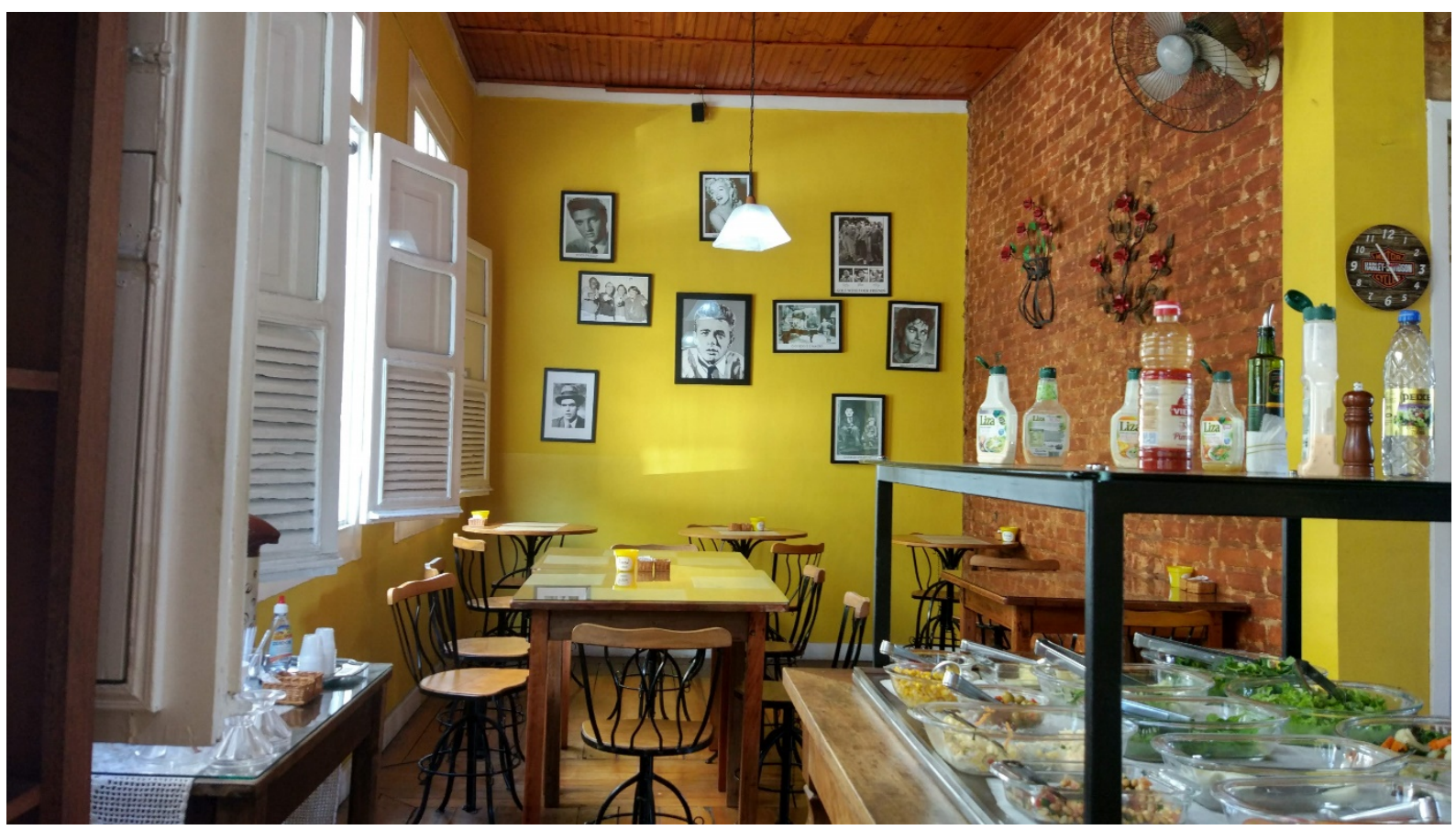

Fonte: arquivo pessoal do autor.

As janelas, a iluminação, a parede e o piso, ainda são originais da casa, que desde o ano de 1998 é um restaurante. Esse é um dos exemplos de obra que não foi tombada e continua em seu estado preservativo de construção. Essa característica faz parte do marketing do restaurante em atrair seus clientes. Também, é o único restaurante que funciona até às 16 horas, por outro lado não funciona à noite.

Próximo ao restaurante, encontramos o Cine Teatro Edgard, que é um monumento tombado pelo IPHAN em 1994, porém atualmente ele não está em funcionamento, infelizmente. O edifício abriga um cineteatro e uma loja no pavimento térreo e, nos dois pavimentos superiores, um grande salão de festas com palco, mezanino e terraços. Chama 
atenção a composição das curvas executadas em concreto armado do salão de festas, a fachada com parede inclinada, o mosaico em ladrilhos hidráulicos, os pilares da fachada, as escadarias curvas, o mezanino e o grande vão da plateia, que mostra o avanço tecnológico da época.

Seu espaço seria de grande uso para a população, principalmente para atrações culturais, porém com a vinda do Shopping/Cinema na cidade, o posto do teatro perdeu a importância para o público, de acordo com o que dizem os moradores e lojistas próximos à praça. Na imagem abaixo é possível até localizar, abaixo do nome do teatro, uma placa com o título: É NOSSO!!!. Nesse caso, refere-se à reivindicação dos artistas, professores e público em geral que quer o funcionamento do teatro de volta, principalmente para as atividades teatrais e educativas.

De acordo com alguns dos lojistas, a reabertura do teatro também beneficiaria a eles, e esse funcionamento só não ocorre por questões de interesse político e de medidas sociais.

Imagem 4 - Vista do Cine Teatro Edgard.

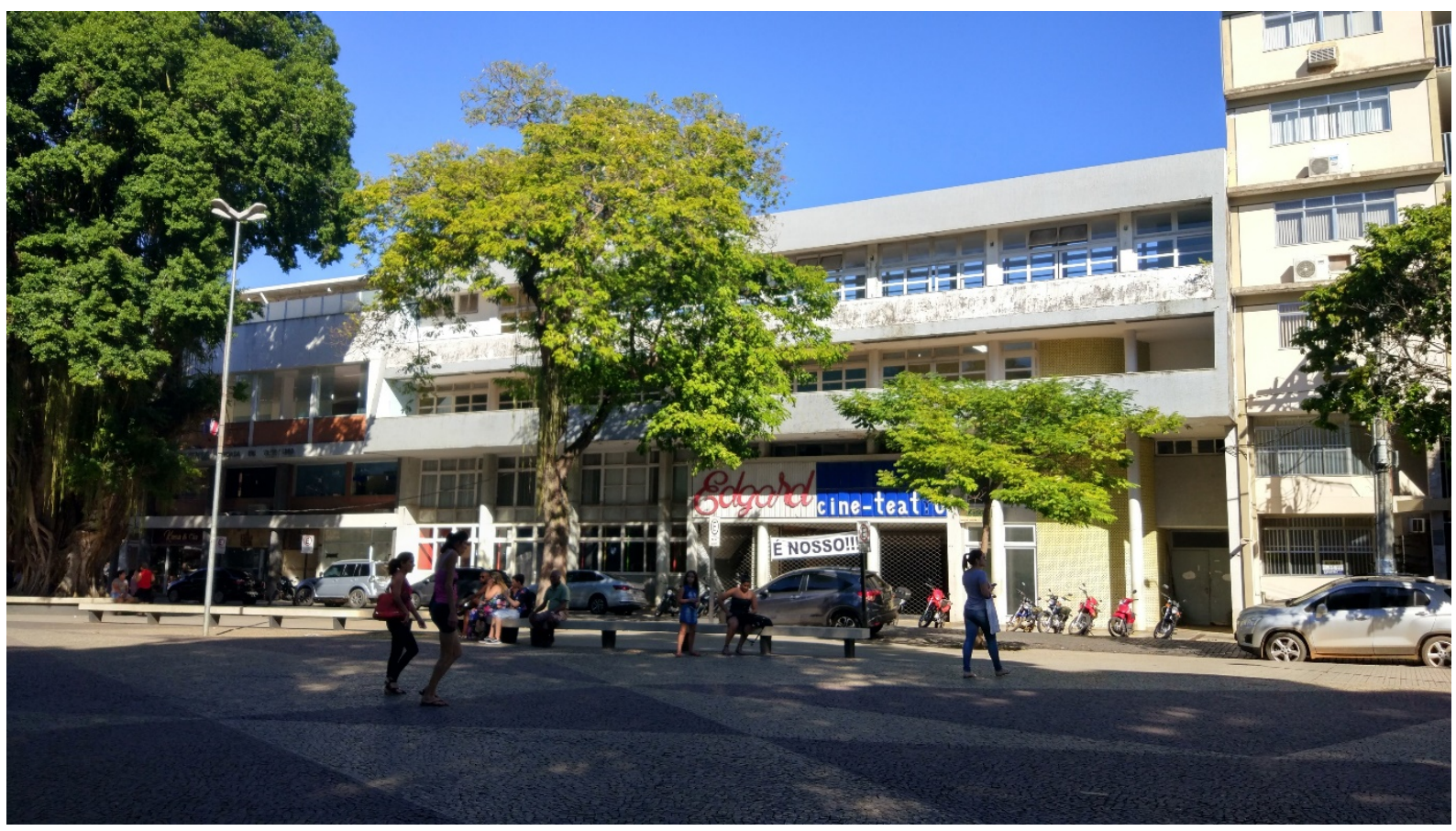

Fonte: arquivo pessoal do autor.

Durante os dias de pesquisa de campo, a Concha Acústica da praça ficou sempre vazia e inutilizada, muitas das vezes em que passava ali, cerca de oito vezes por dia, observava a presença de um morador de rua ou alguém com skate ou bicicleta. Isso deixa de lado o propósito da concha acústica e sua utilidade é praticamente morta por motivo de falta de uso. 
Parte de sua arquitetura foi tomada por pichação, como pode ser observado na imagem abaixo e as pessoas se utilizam mais dos bancos que estão espalhados pela praça. Outro detalhe: à noite, a Concha Acústica não possui nenhuma iluminação em seu interior, representando mais um descaso com o monumento tombado. A iluminação da praça é localizada principalmente em seus arredores, principalmente próximo às lojas.

Imagem 5 - Concha Acústica da Praça Manoel Inácio Peixoto.

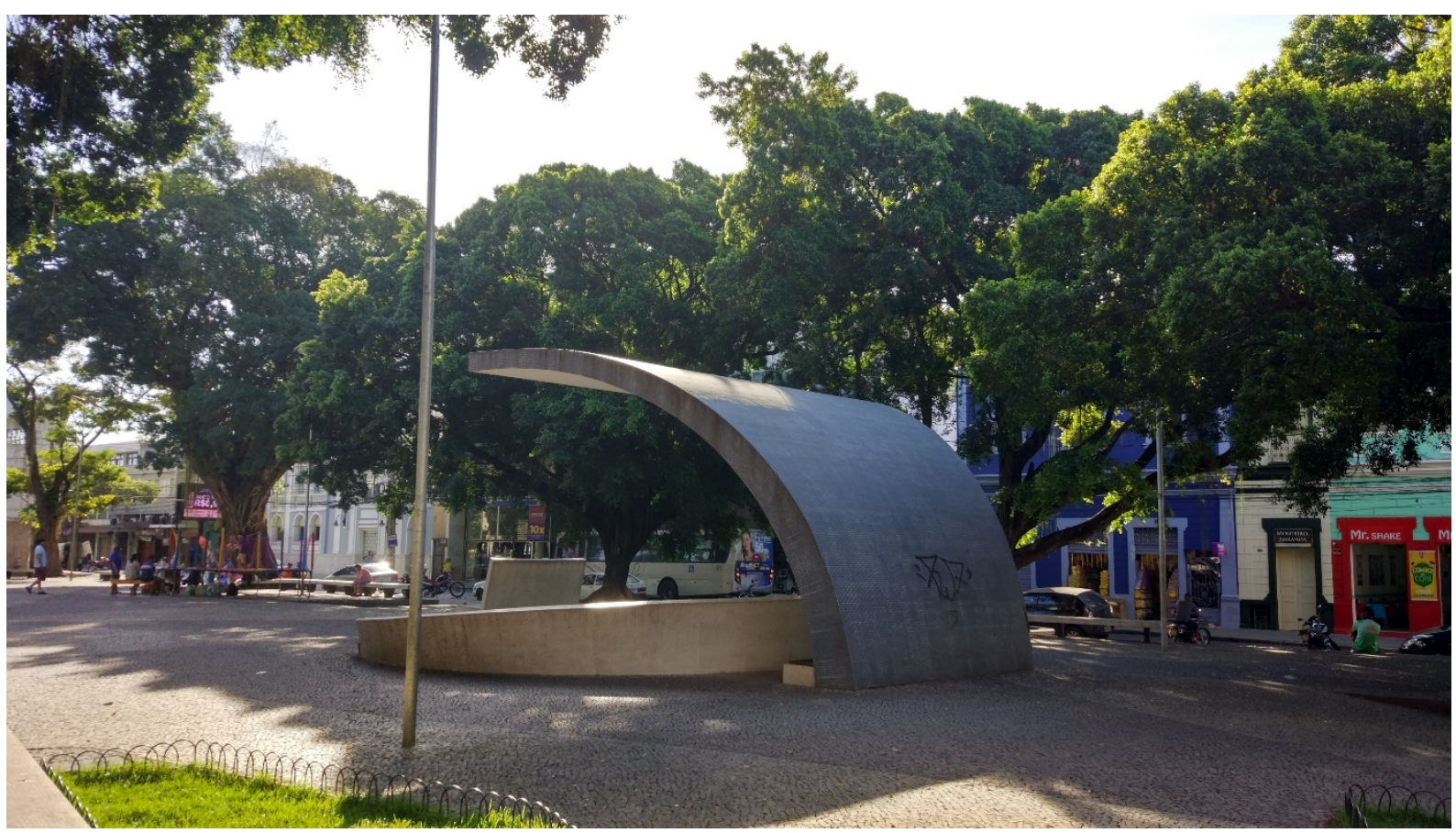

Fonte: arquivo pessoal do autor.

Vizinho à Praça Rui Barbosa, mais especificamente na esquina antes de se aproximar da Concha Acústica, há um edifício que chama atenção por seu contexto histórico: a Loja Maçônica Cataguazense, fundada em 1988, um monumento não tombado pelo IPHAN. Em conversa com um servidor público na ida para a sede do IPHAN em Cataguases, este monumento representa uma grande parte da história de Cataguases, porém, por questões políticas e de discursões entre agentes de Patrimônio e até mesmo por questões religiosas, o edifício não foi tombado, mesmo trazendo uma riqueza histórica para a cidade.

A visita a seu interior é restrita, por questões de crença, não sei dizer se é religiosa, mas na parte de baixo, ainda na praça, é possível visualizar parte do que há dentro do edifício, como quadros, esculturas e bandeiras, por exemplo. Na parte de baixo do Edifício, existem duas lojas comerciais: uma de utensílios para residência e uma sorveteria. Contudo, em conversa com esses lojistas, as lojas são alugadas, o que indica que o edifício é de domínio 
particular. A arquitetura proveniente deste edifício, a meu ver, é proveniente e bem semelhante as da década de 40 e 50, o que a caracteriza como uma arquitetura mais moderna.

Imagem 6 - Loja Maçônica Cataguazense.

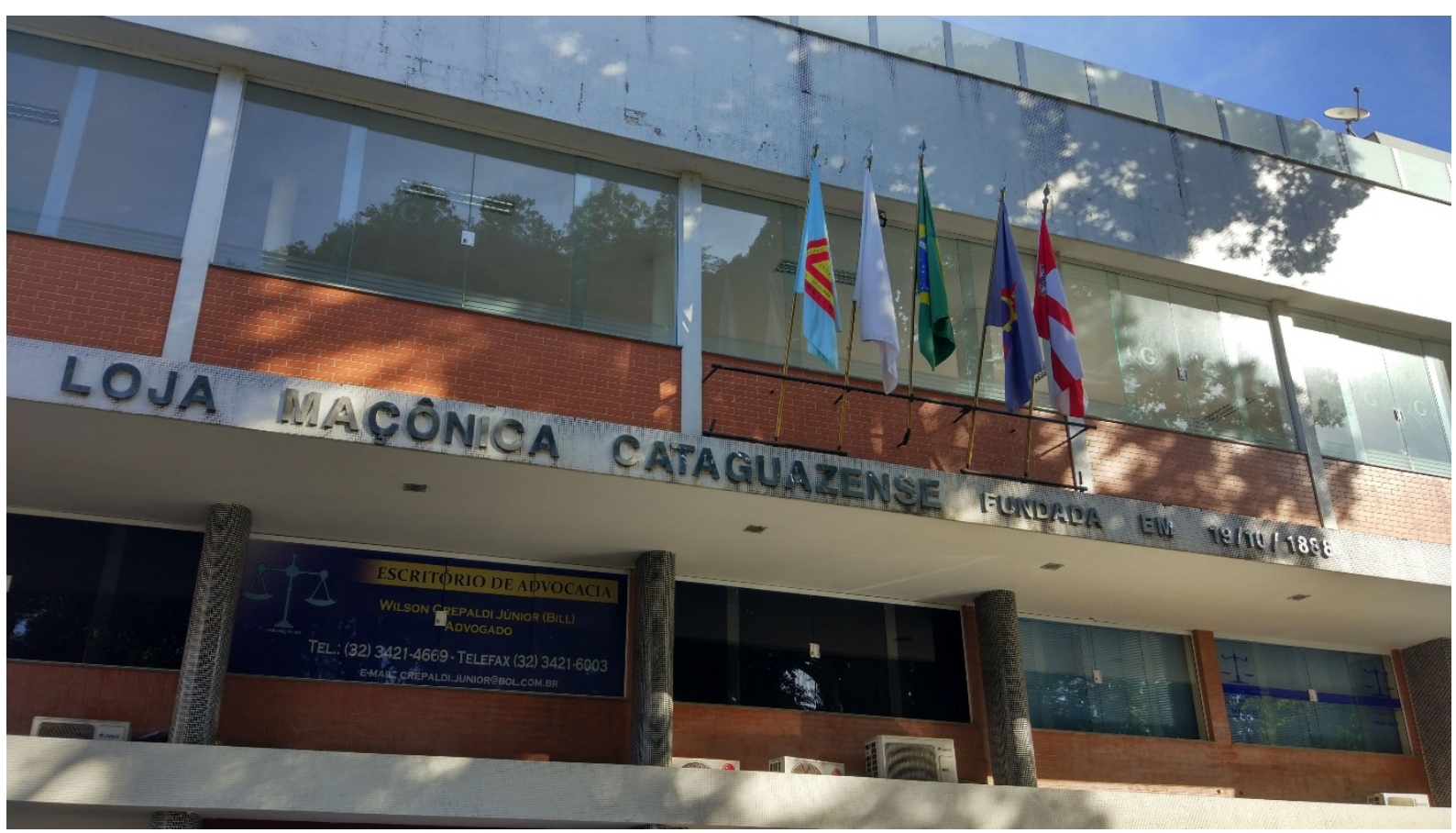

Fonte: arquivo pessoal do autor.

Saindo da praça, encontramos logo a 700 metros, a prefeitura da cidade, um monumento tombado pelo IPHAN, e é onde funciona até hoje os núcleos administrativos da cidade. A entrada da prefeitura é livre para o público, e em seu interior é possível realizar imagens e ter acesso a diversos documentos que relatam a história de Cataguases, mesmo ainda quando era um vilarejo. 
Imagem 7 - Prefeitura Municipal de Cataguases.

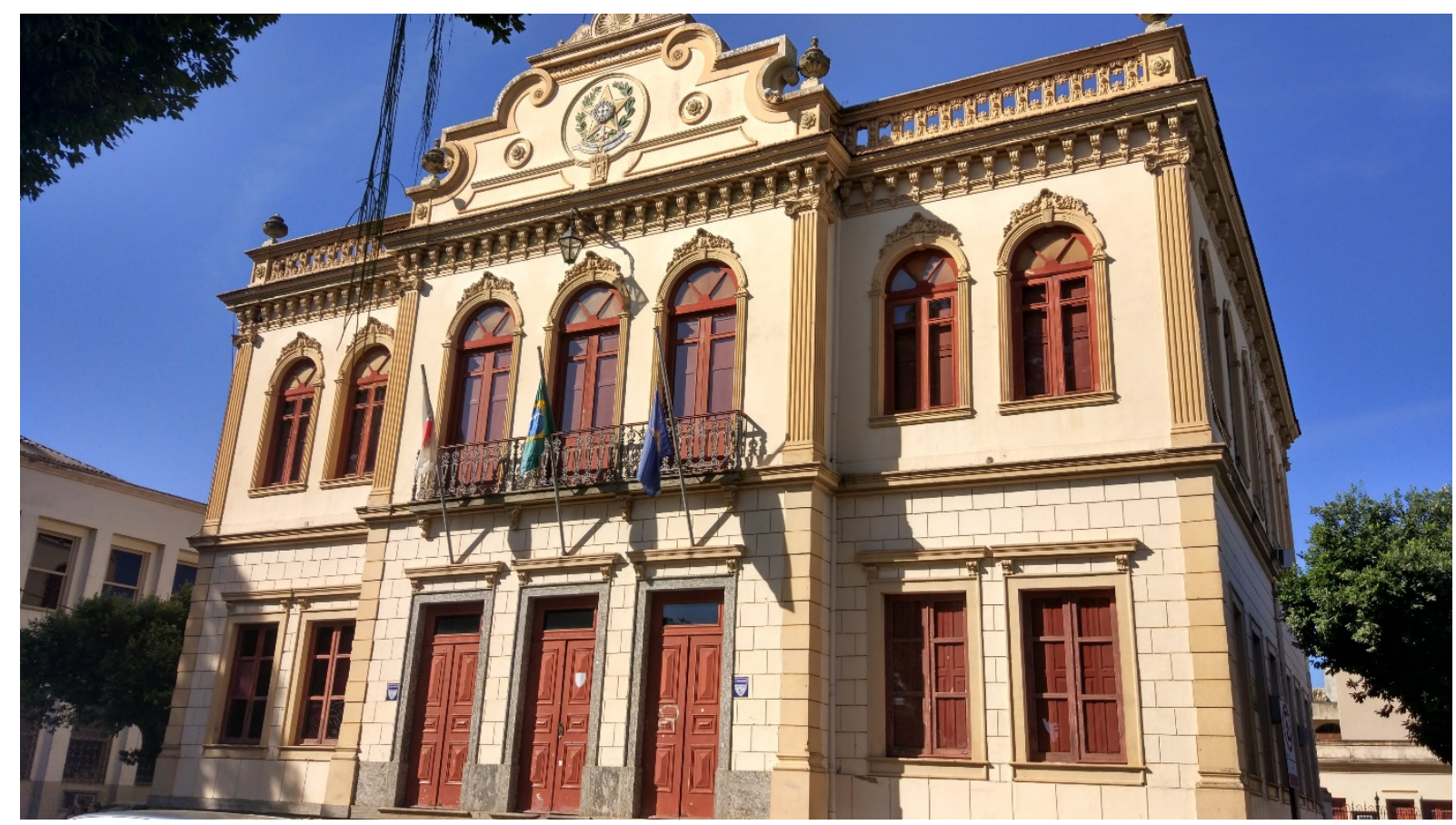

Fonte: arquivo pessoal do autor.

A prefeitura de Cataguases foi construída e fundada em 1895, um dos primeiros edifícios a serem erguidos na cidade, sendo desde o início estabelecido para ser a sede administrativa da cidade. Apesar da arquitetura colonial do edifício, alguns de seus móveis possuem traços mais modernistas, assim como o anexo que foi construído após os anos 1990 na parte de trás do prédio principal da prefeitura.

Muitos turistas gostam de subir no segundo andar do prédio para comtemplar a vista da praça em frente à Igreja, além de se esconder um pouco do sol que se faz nas regiões de Minas Gerais. No interior da Prefeitura é possível ter acesso à sala de reuniões que, apesar de desativada em 1991, ainda é aberta para visitação. Aqui também se encontram fotos dos prefeitos e administradores da cidade, desde o ano de 1898. Na imagem a seguir, é possível ver como é a sala e como estão despostos os quadros na parede. 


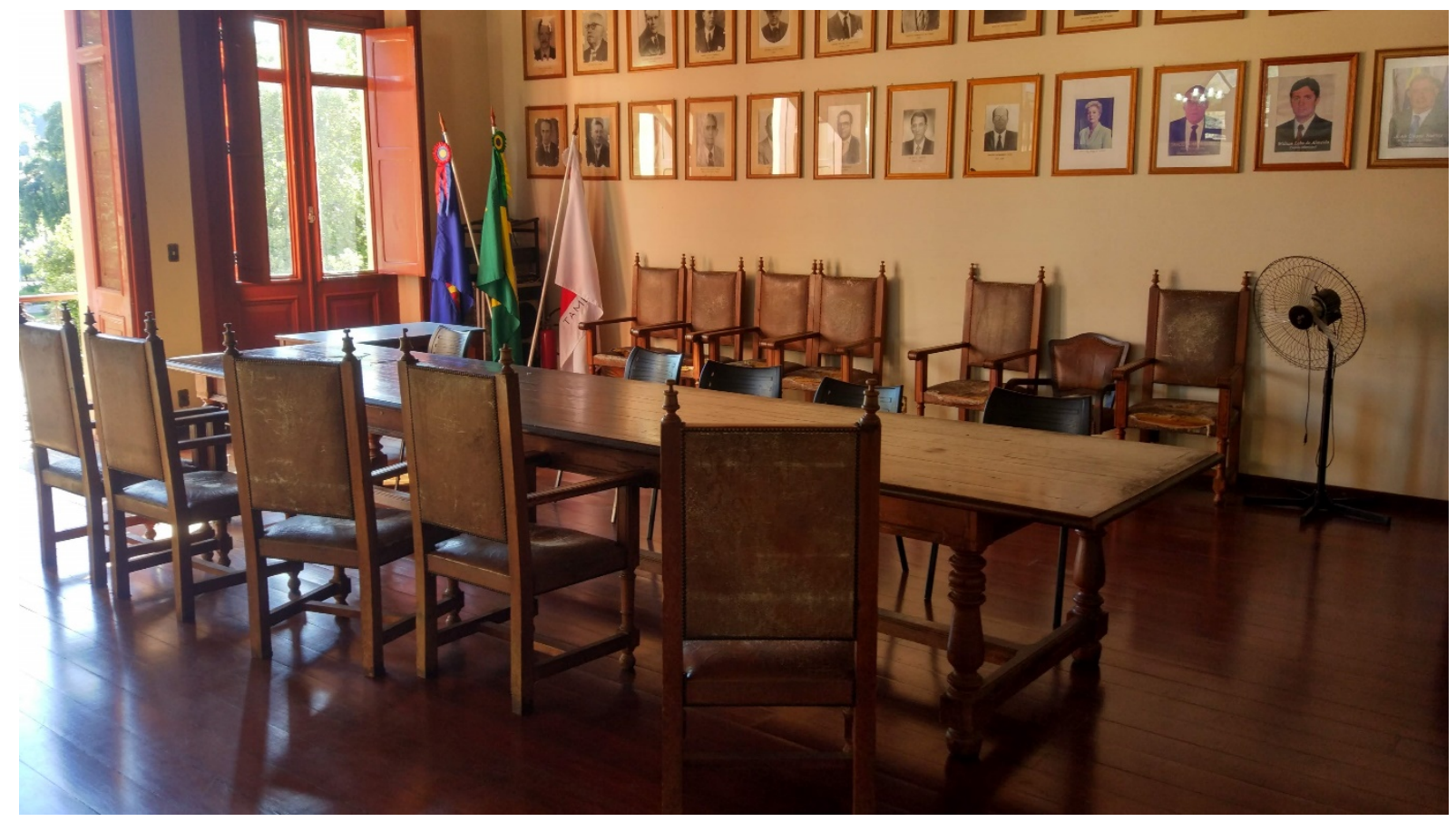

Fonte: arquivo pessoal do autor.

\subsection{Igreja Matriz de Santa Rita de Cássia}

Logo depois da Prefeitura, encontramos talvez o mais importante monumento para muitas das pessoas na cidade, a Igreja Matriz de Santa Rita de Cássia, com a sua capela logo ao lado, que foi construída um pouco depois. A ida a igreja se deu em dois momentos diferentes: a participação na missa do domingo à noite, e durante o dia, com a visita à capela, aberta 24 horas. A Igreja comporta cerca de 400 pessoas e aos domingos a missa é lotada de fiéis, sendo que parte deles vem de cidades vizinhas, principalmente de Além Paraíba - RJ.

A igreja, de autoria do arquiteto Edgar Guimarães do Vale, possui caráter modernista e se destaca pela ousadia das suas formas curvas conjugadas com uso do concreto armado, muito diferente do que se esperava para uma igreja da época em que foi projetada. Também chama a atenção o grande painel em azulejos azuis de sua fachada principal intitulado "A Vida de Santa Rita", obra da pintora Djanira. Já as pinturas existentes no interior da igreja foram instaladas no ano de 1996, representam a Via Sacra e são obras da artista plástica Nanzita Salgado.

$\mathrm{Na}$ imagem a seguir vemos a igreja com sua única torre de formato ogival e a entrada para a capela que sempre está de portas abertas. O interior da capela é bem mais simples que o 
interior da igreja, porém ainda apresenta traços da arquitetura modernista. Possui um pequeno altar com iluminação indireta e recortes de gesso na parede ao fundo e no teto, além da presença de uma tela de LCD. As imagens sacras estão representadas apenas pelos vitrais instalados nas janelas da capela.

Imagem 9 - Vista da Igreja Matriz de Santa Rita de Cássia.

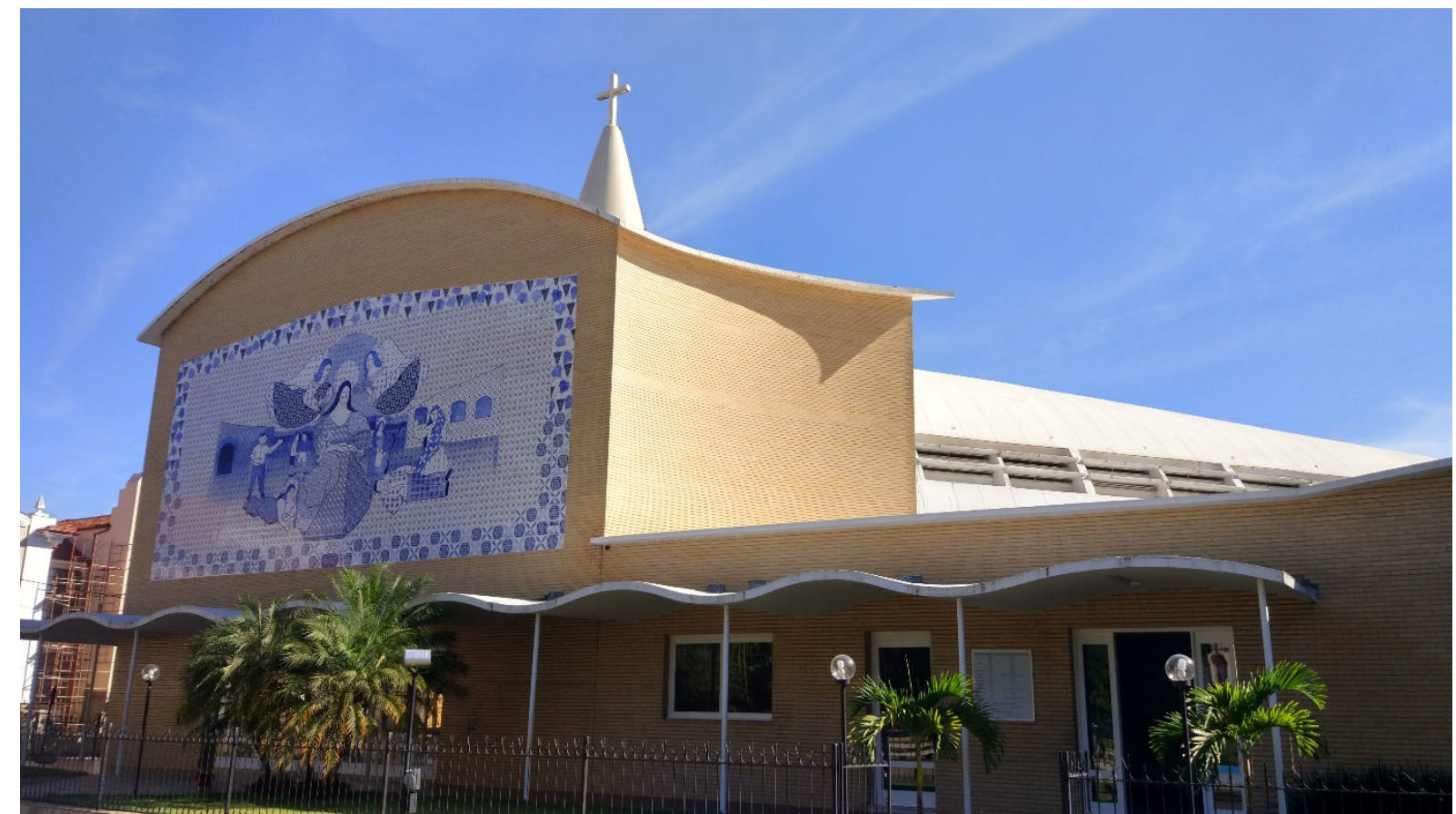

Fonte: arquivo pessoal do autor.

As imagens desenhadas na capela e as esculturas são recentes e bem trabalhadas. É interessante observar que, para cada item existente na capela, como um banco de madeira ou uma escultura, é definido quem contribuiu financeiramente para aquela peça, como por exemplo: "Contribuição da família Silva". É conveniente lembrar que a capela é uma parte não tombada pelo IPHAN, apesar de estar no mesmo lote/quadra da igreja. Vale ressaltar que o público que visita a capela é composto apenas dos moradores locais, diferentemente da igreja que recebe fiéis de outras cidades vizinhas. 
Imagem 10 - Capela da Igreja Santa Rita de Cássia.

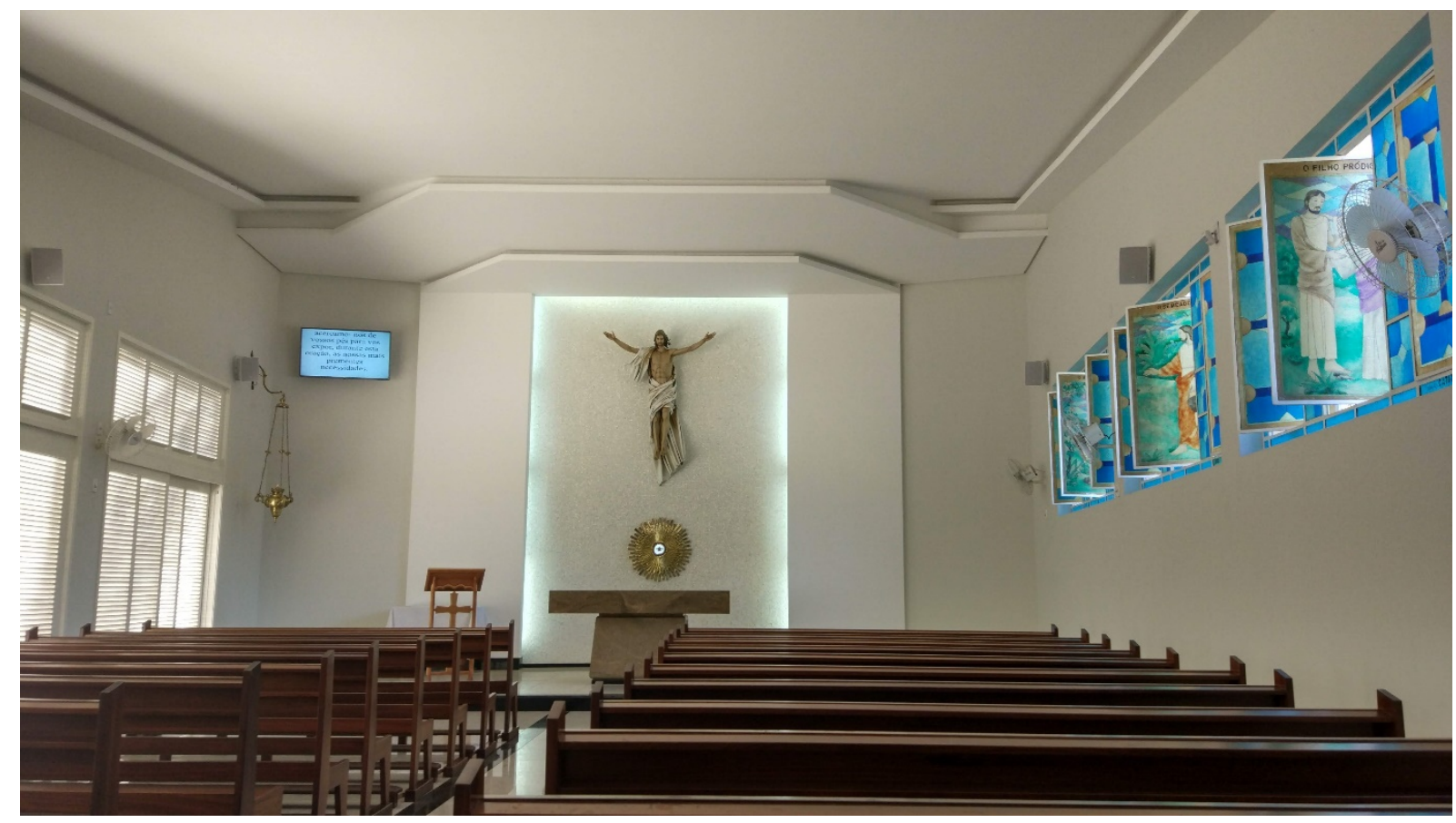

Fonte: arquivo pessoal do autor.

O interior da igreja é uma parte gloriosa de se conhecer. Toda a acústica e ambientação da igreja é uma mistura de sensações por se estar em um ambiente tão moderno e espiritual ao mesmo tempo. Isso também se refere ao misticismo das pinturas encontradas nas paredes, à iluminação obscura e simples que ora se oculta, ora se revela e às características das esculturas que são peças trazidas de outras regiões. No projeto original, encontrado no Guia de Cataguases oficial, a acústica da igreja foi um dos pontos principais definido pelo arquiteto Edgar Guimarães do Valle em sua construção. Podemos perceber que o desenho da igreja nos fornece essa sensação de que o som se propaga facilmente no ambiente.

$\mathrm{Na}$ imagem a seguir podemos observar como é a parte interna da igreja. Uma das características mais interessantes de se observar é que as pinturas não são diretamente iluminadas, e só é possível vê-las se chegar bem próximo a elas. A iluminação interna foi feita com o uso de umas das tecnologias mais modernas da atualidade, os leds. Na capela percebese pela imagem que toda iluminação é feita com os leds em volta da imagem de Cristo, enquanto que no interior da igreja há uma mistura de cores que torna o ambiente mais calmo e obscuro. A iluminação indireta é uma característica bem modernista da igreja. 


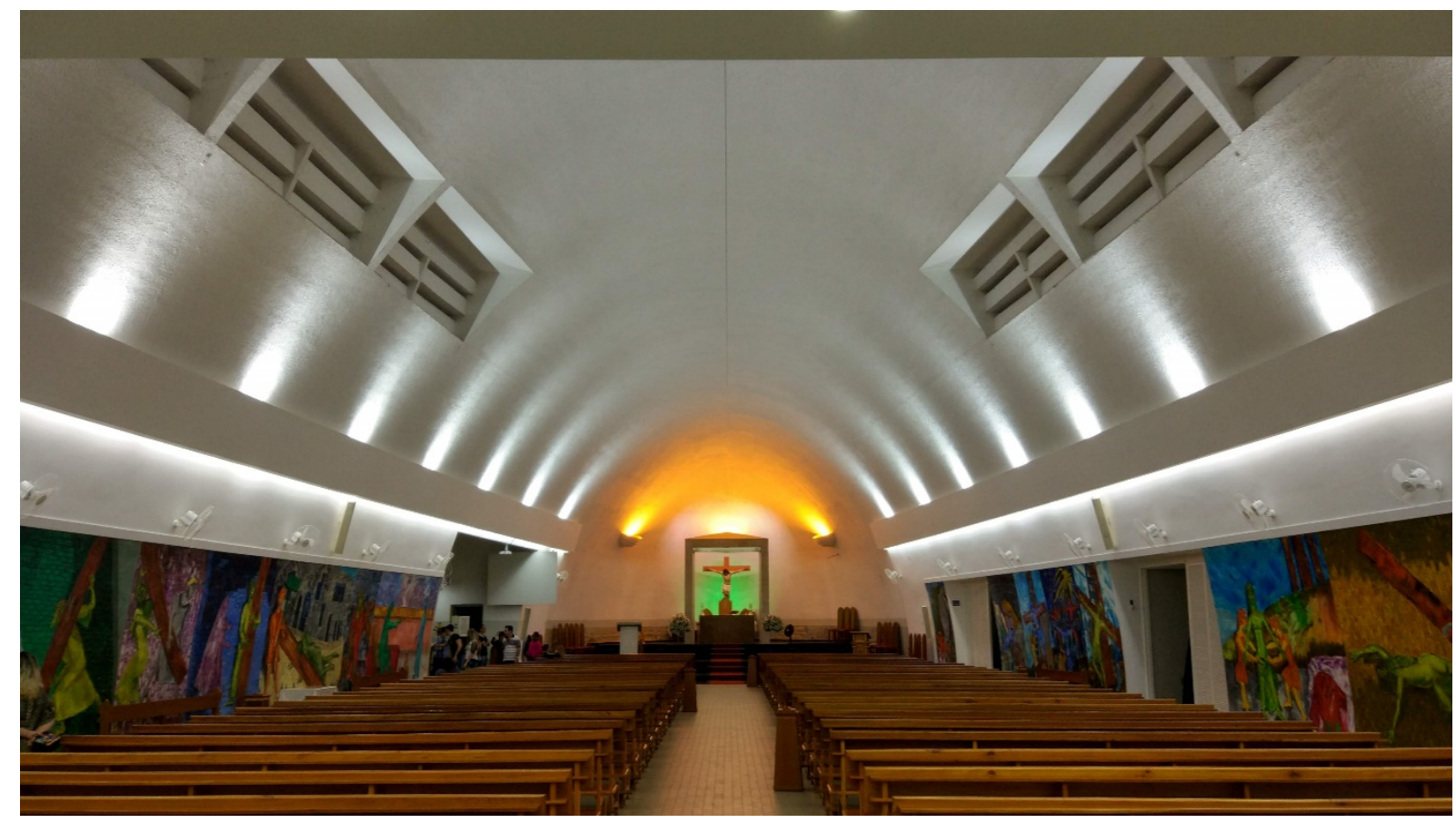

Fonte: arquivo pessoal do autor.

Outro ponto a ser observado nas paredes da igreja é a imagem de Santa Rita de Cássia, colocada estrategicamente abaixo de um desenho esculpido no teto, que pode representar a iluminação pessoal da presença de Santa Rita de Cássia. O mais interessante de se visitar a igreja a noite foi perceber os reflexos de luz existentes em todos os lados da igreja, o que é visto também na imagem da Santa. 
Imagem 12 - Imagem de Santa Rita de Cássia.

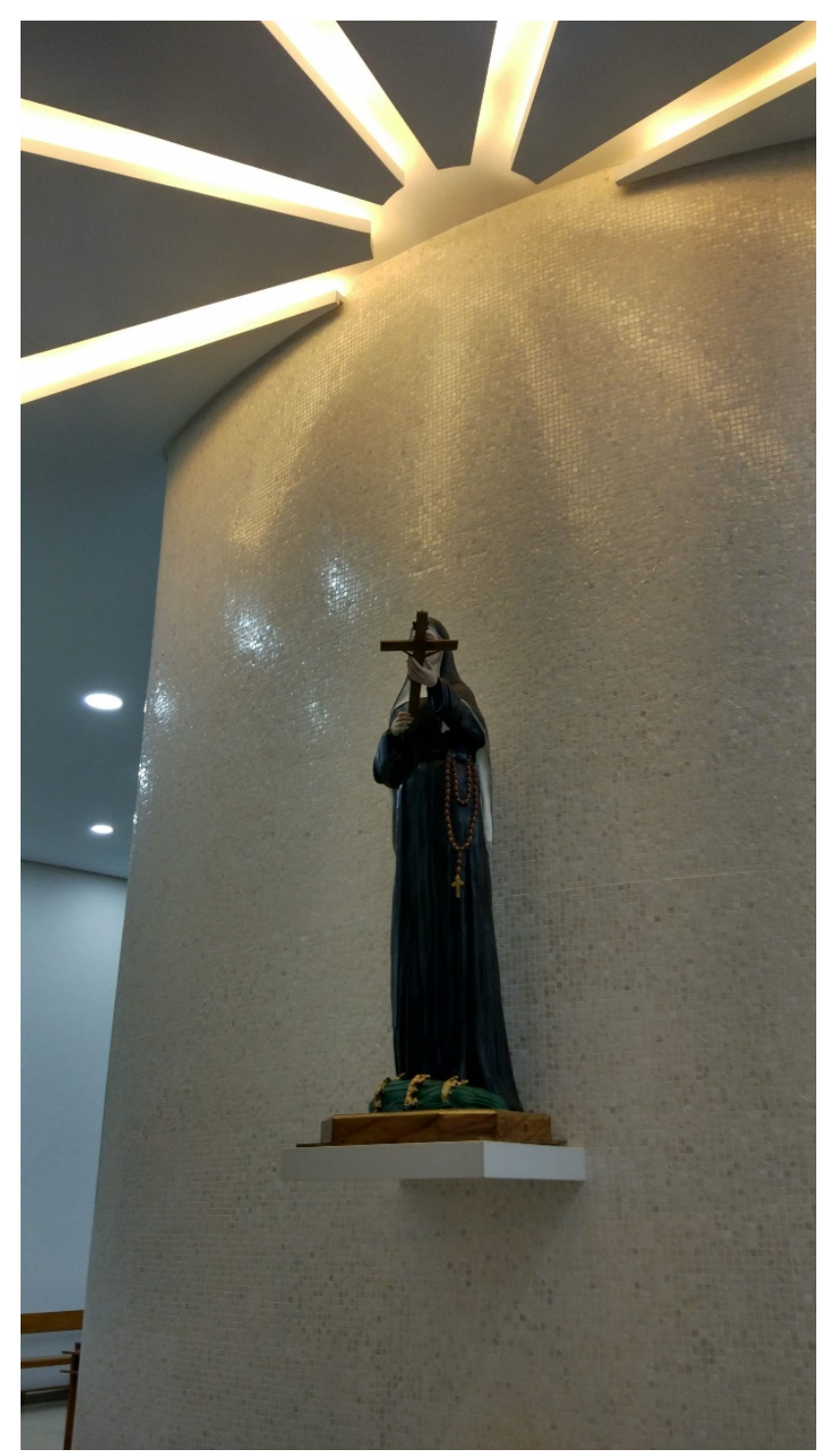

Fonte: arquivo pessoal do autor.

Situada ao lado esquerdo da entrada principal da igreja, está a escadaria principal da igreja. Porém, o acesso a essa escada é restrito, visto que o toque do sino é realizado apenas por um membro fixo da igreja, limitando o acesso para o público externo. Pela imagem a seguir podemos perceber que o desenho helicoidal da escada de concreto é de uma característica bem modernista, porém o corrimão metálico parece ter sido instalado mais tarde por razões de segurança, já que ele não conversa bem com o tipo de material utilizado no interior da igreja. 
Imagem 13 - Escadaria que leva ao sino na Igreja Santa Rita de Cássia.

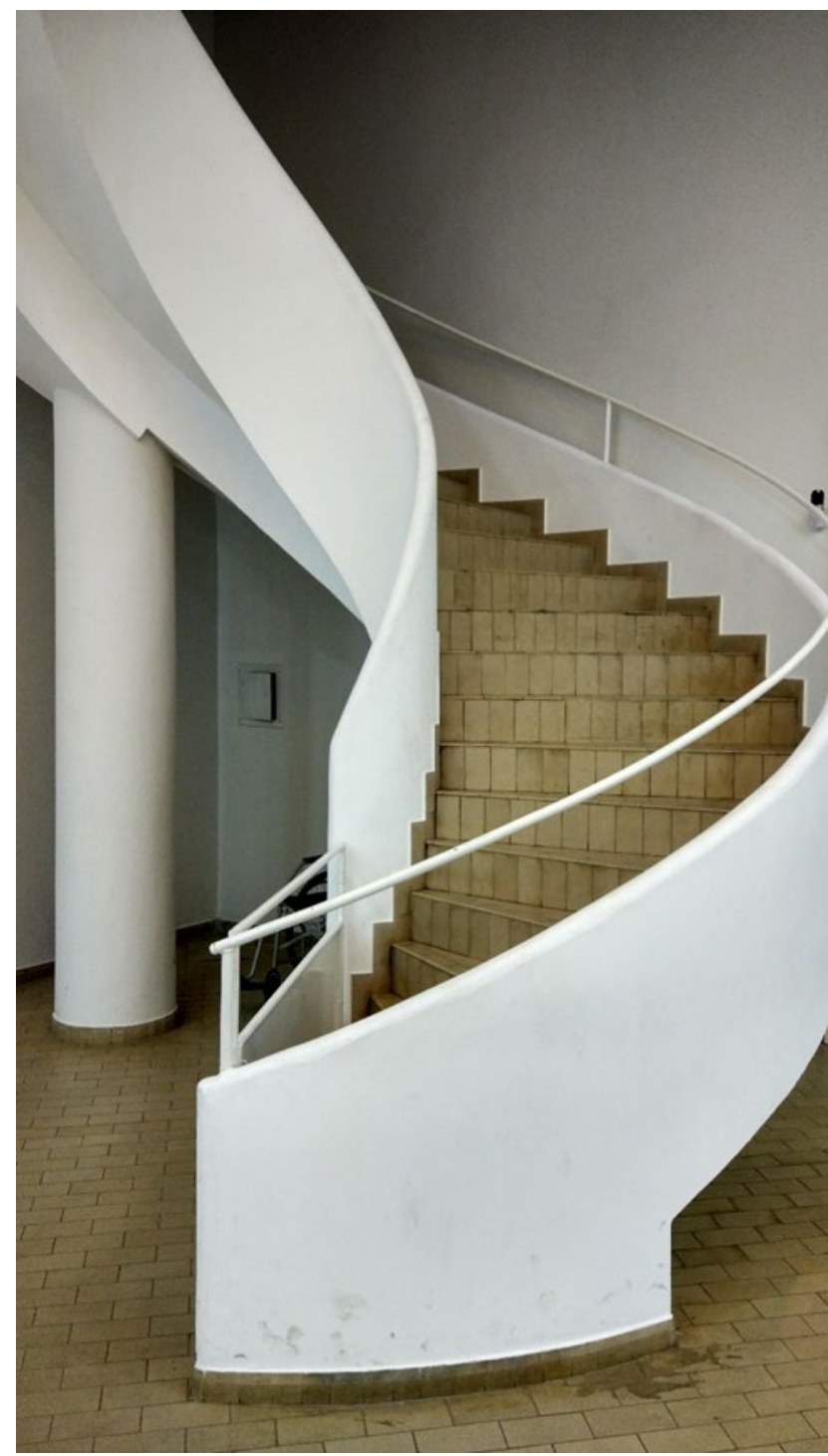

Fonte: arquivo pessoal do autor.

$\mathrm{Na}$ imagem abaixo temos a planta baixa da igreja, retirada do Guia de Cataguases oficial. A imagem é composta de uma legenda para facilitar a localização de cada cômodo interno e externo à igreja. Na planta baixa é possível perceber bem as curvas modernistas que embasam a construção do edifício. 
Imagem 14 - Planta Baixa da Igreja de Santa Rita de Cássia.
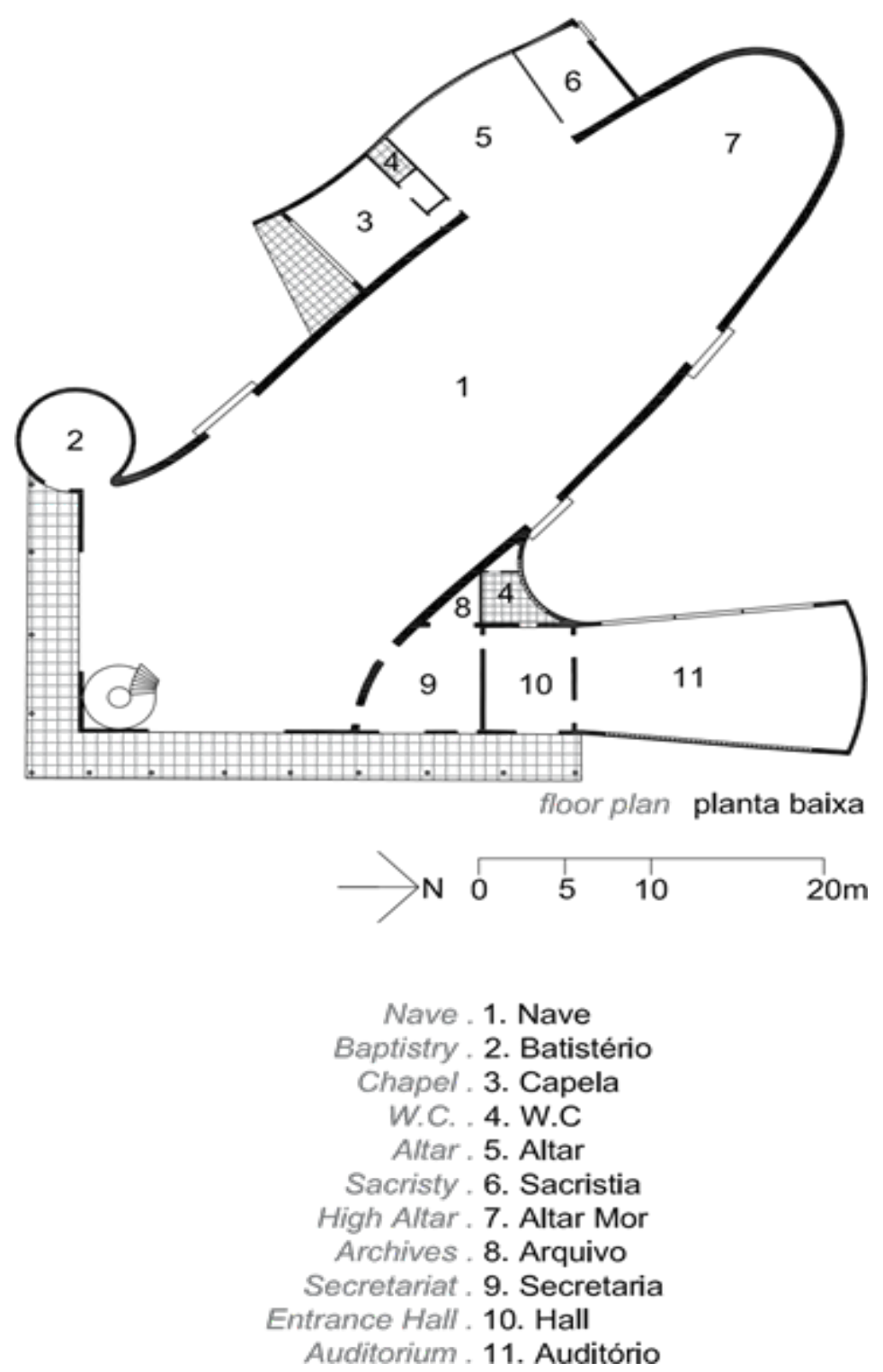

Fonte: (VALLE, 1996).

Na saída da igreja, somos comtemplados com uma pintura realizada pela comunidade cristã que representa a paz no mundo, paz essa que é representada pela pomba branca iluminada. Os continentes são representados pela cor rosa, enquanto que o Brasil em especifico é representado pela cor amarela, mesma cor utilizada ao redor da pomba branca. A sensação que ocorre ao observar a pintura é a sua relação direta com as outras pinturas presentes no interior da igreja. Além disso, você se sente acolhido vislumbrando a pintura ao sair da igreja. Provavelmente essa arte quer passar para nós um certo sentido de conforto. 
Imagem 15 - Pintura na saída da Igreja de Santa Rita de Cássia.

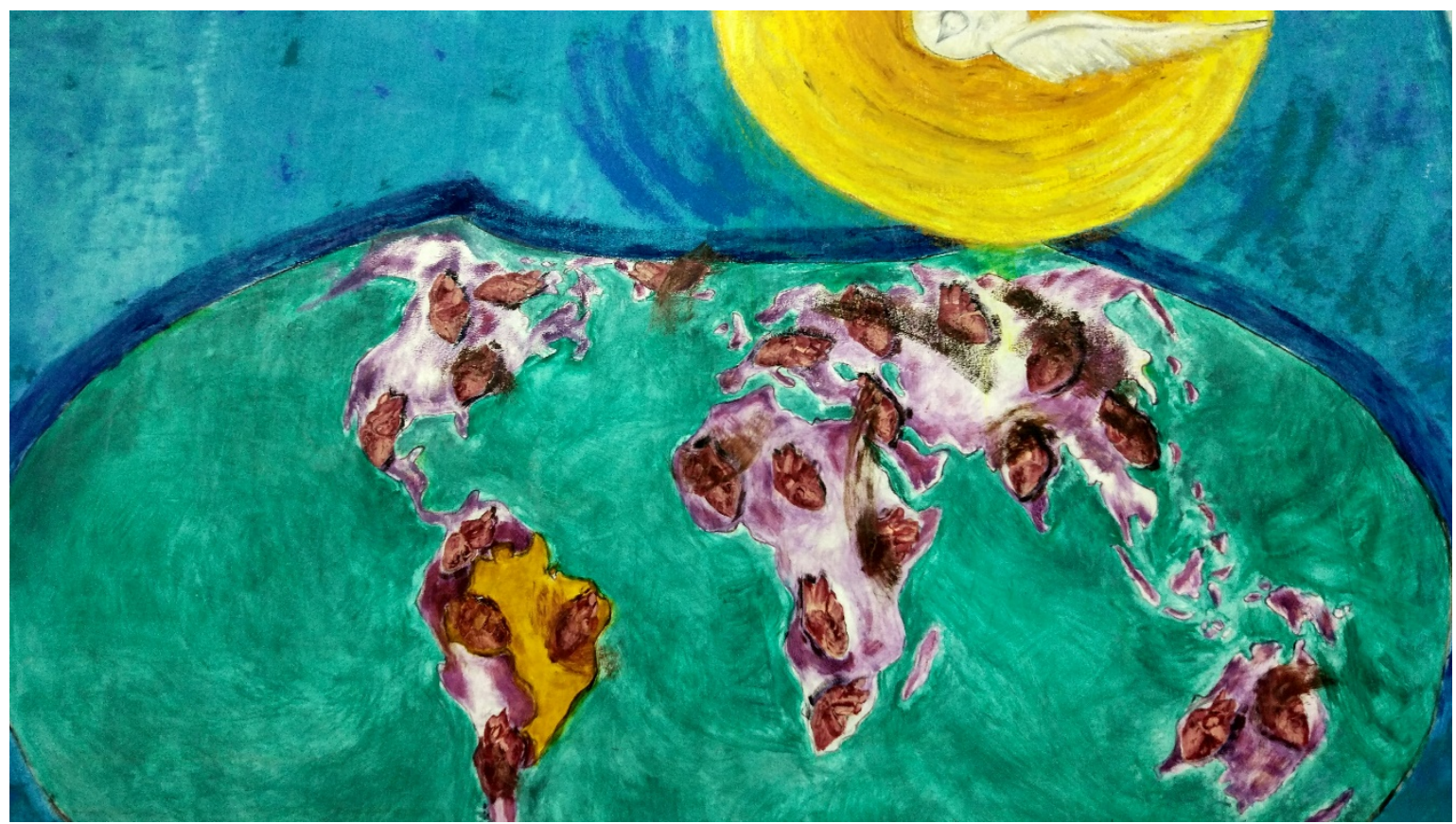

Fonte: arquivo pessoal do autor.

\subsection{Setor Histórico Industrial}

A partir desse momento irei argumentar um outro lado da cidade antes de seguir para o centro. Neste lado percebe-se que, durante vários anos atrás, existia uma área de indústria, visto a facilidade de comercialização com cidades do interior do Rio de Janeiro e de Minas Gerais, como Juiz de Fora por exemplo. Atualmente é uma parte de pouca movimentação de pessoas, sendo que a maioria delas acessam a região por ônibus coletivo ou transporte próprio como carros e motos. O trajeto a pé tem início pela famosa ponte de Cataguases, que seja talvez o maior "cartão-postal” da cidade, chamada apenas de Ponte Metálica que atravessa o Rio Pomba.

O Rio Pomba de fato divide a cidade em duas regiões. Nomeei-as, a título de patrimônio histórico, de industrial e cultural, sendo que a região "industrial" é aquela além da ponte e a "cultural" é a que contempla o centro da cidade de Cataguases. Na região industrial temos três pontos tombados pelo IPHAN como patrimônio histórico: a Vila Operária do Bairro Jardim, o monumento dedicado a José Inácio Peixoto e o Sindicato dos Trabalhadores de Energia Elétrica. Porém, visitando os locais, o maior ponto de encontro da comunidade 
local, ou seja, o que tem mais importância como utilidade pública, é o Clube do Remo, que inclusive conta com atividades no Rio Pomba com esportes como Remo e Vela.

Voltando a entrada da região industrial, o principal acesso caminhando é a Ponte Metálica. A construção da Ponte Metálica foi definida em 1910, ela foi erguida para substituir a ponte anterior, de 1842, feita em madeira, que ligava o núcleo urbano de Cataguases à margem oposta do Rio Pomba, que corta a cidade. Com material importado da Alemanha e mão-de-obra especializada, vinda de fora, as obras foram iniciadas dois anos depois e finalizadas em 1914. Todas essas informações estão descritas em uma placa de metal localizada na entrada da ponte.

Em 20 de junho de 2015 a ponte completou 100 anos, ano em que recebeu uma nova pintura da cor original de sua inauguração: o vermelho. Por isso a maioria das imagens que vemos na internet, a ponte está na cor branca. A imagem a seguir representa a nova interface da Ponte Metálica. Importante perceber que daí já tem uma característica modernista da época, pois a arquitetura da ponte se assemelha a de pontes famosas como a de São Francisco, nos Estados Unidos.

Imagem 16 - Ponte Metálica sobre o Rio Pomba.

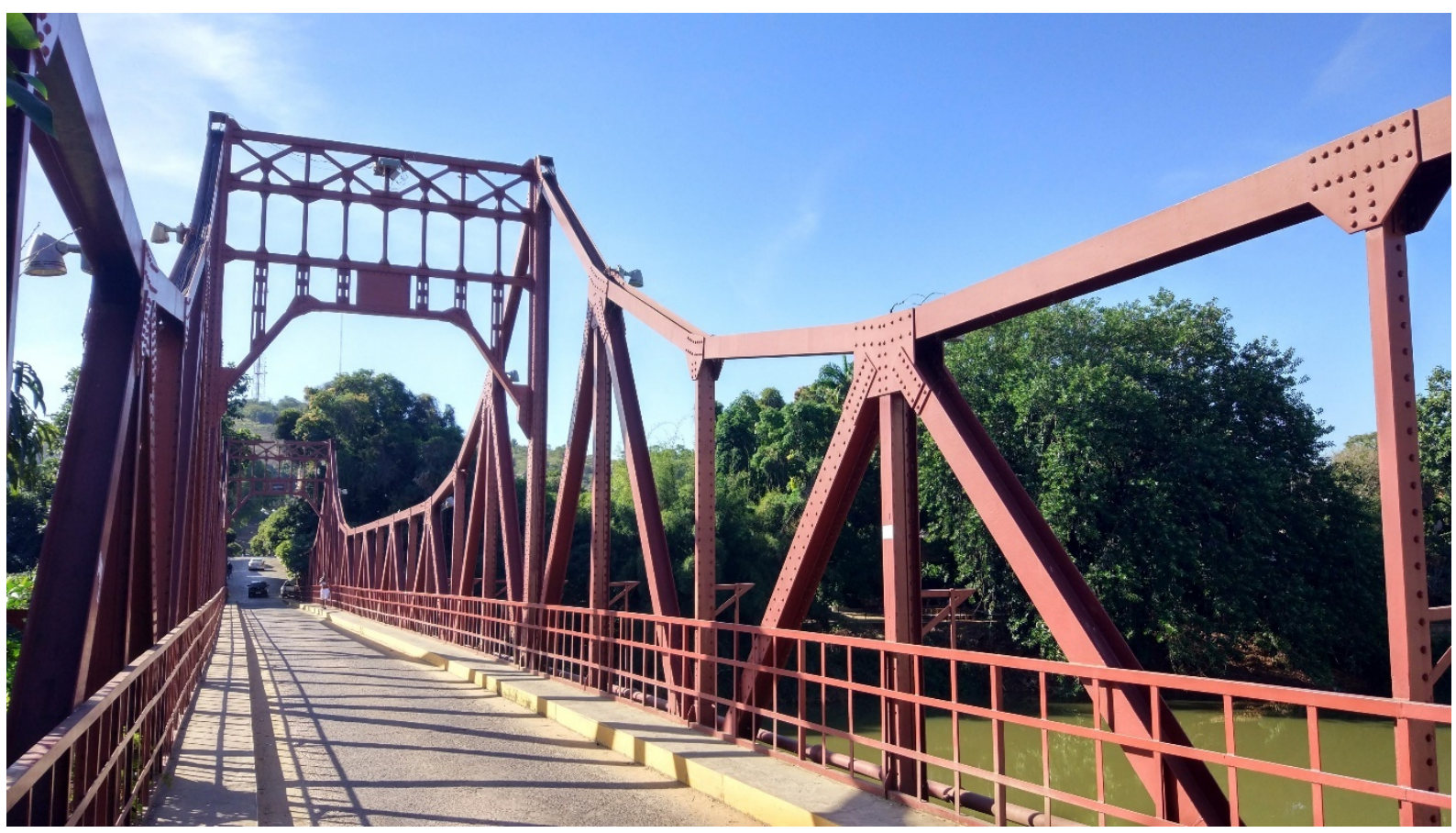

Fonte: arquivo pessoal do autor.

Antes, porém, de adentrar a ponte observei um edifício antigo e abandonado próximo a ela. Indo investigar mais a fundo, pois também moram muitos gatos (dos quais gosto muito) 
ali naquele edifício, vi que se tratava do edifício antigo da delegacia de Polícia Civil de Cataguases. A pergunta veio logo em seguida: Por que esse edifício não foi tombado pelo IPHAN? E sim, em pesquisa nos arquivos históricos da sede do IPHAN, o fato de não ser tombado o edifício justifica-se por questões políticas na época dos tombamentos da cidade de Cataguases em 1994. Esse edifício foi alvo de muitas brigas políticas, e por isso não é muito citado em livros e pesquisas. A seguir apresento uma imagem do edifício.

\section{Imagem 17 - Antigo Edifício da Polícia Civil de Cataguases.}

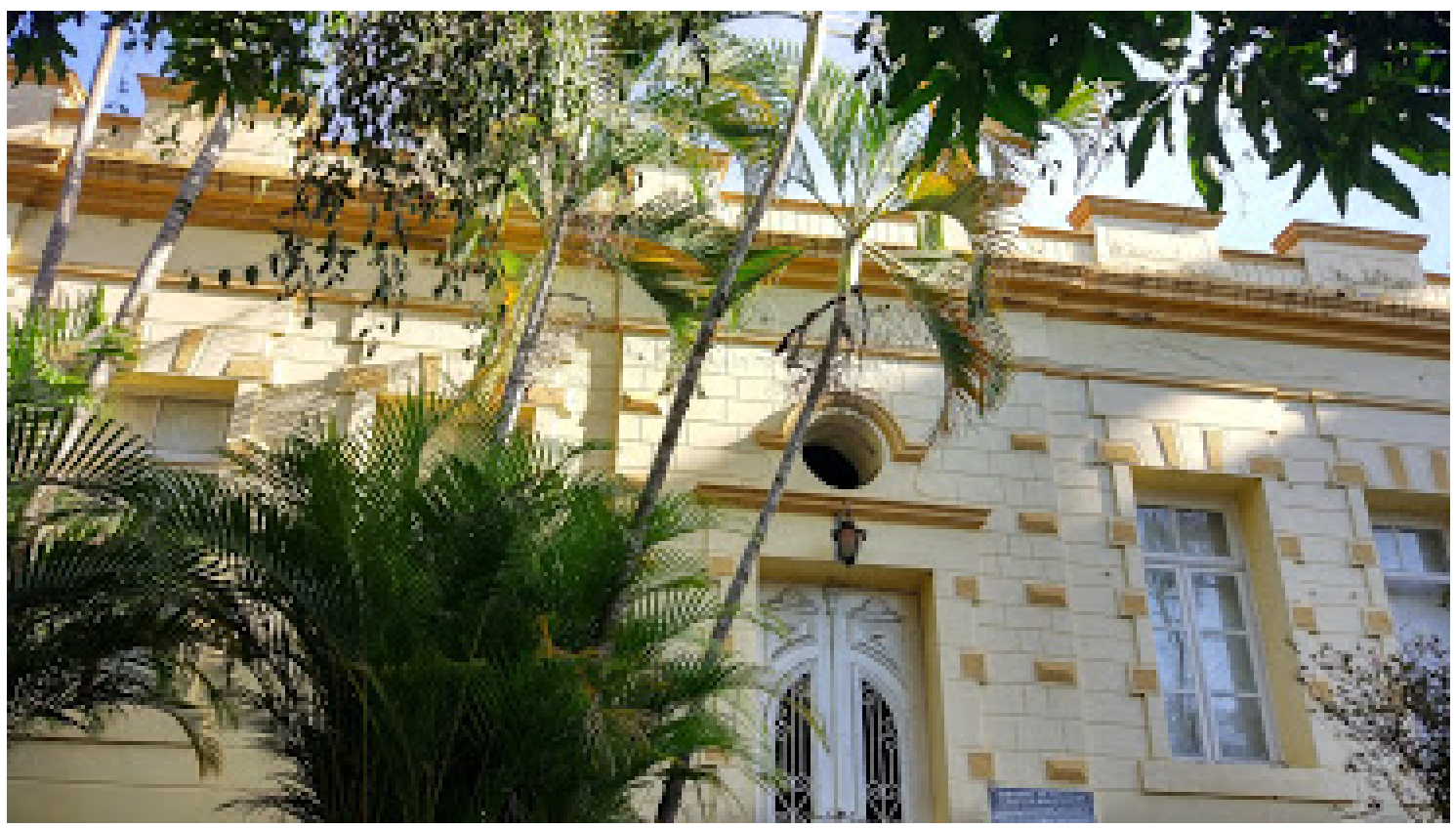

Fonte: arquivo pessoal do autor.

Após terminar o trajeto da ponte, chegamos quase que na entrada do Clube do Remo, tendo acesso também a Vila Operária Companhia Industrial, como é chamada no documento de tombamento. As limitações de construção ou reforma de casas desta vila são muito limitadas e, diante dessa informação, o que encontrei foi o descaso generalizado de algumas obras arquitetônicas na região. Porém, muitas casas ainda mantêm seu padrão antigo que curiosamente se diverge das características arquitetônicas das maiores obras da região que são tombadas, como o Sindicato de Trabalhadores de Energia Elétrica e a Ponte Metálica. O interessante é perceber que a área vegetativa da cidade é extremamente conservada, com árvores que chegam a ter mais de 100 anos de idade. Com a imagem a seguir podemos visualizar um pouco da vegetação e das casas da Vila Operária. 


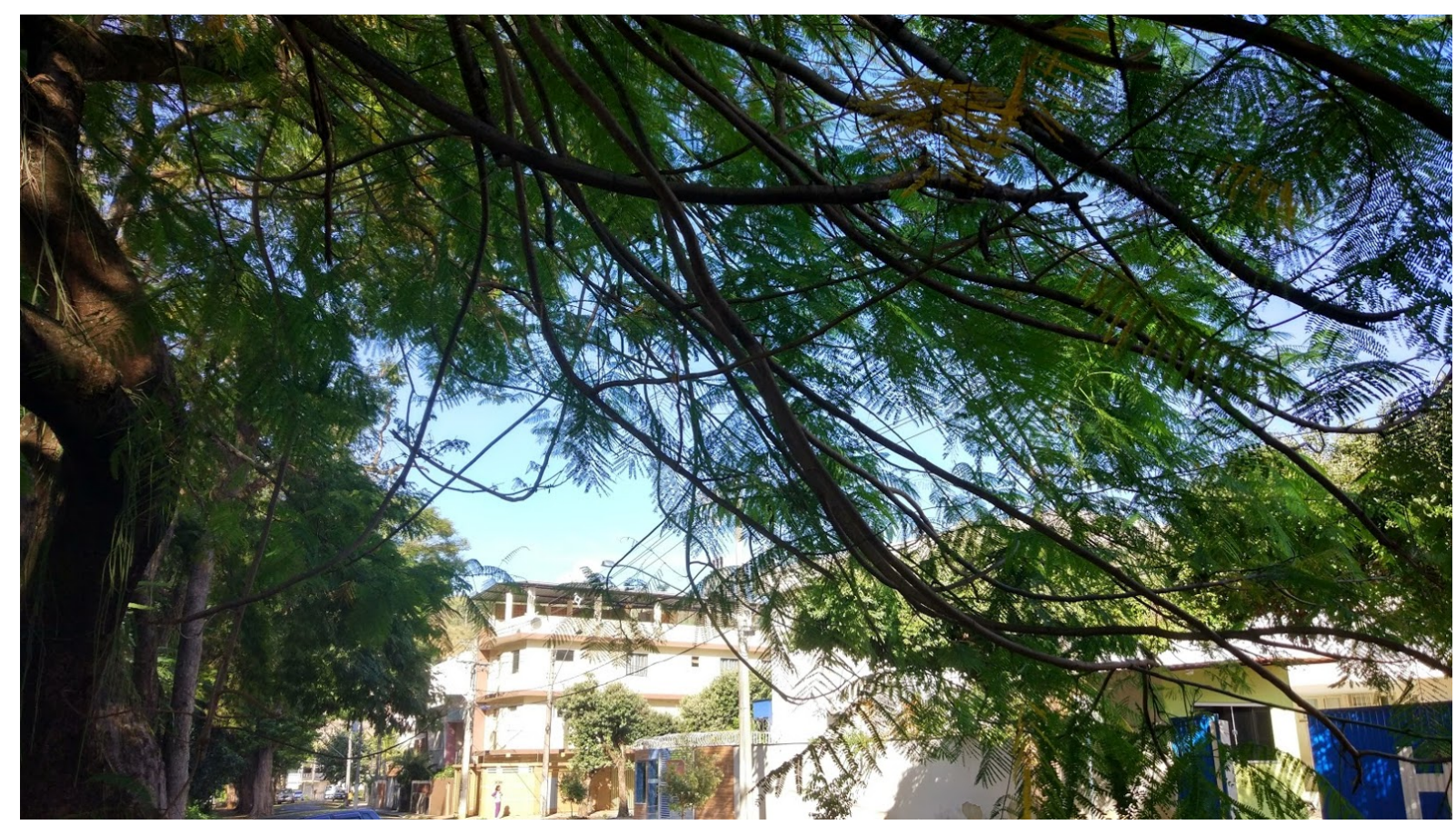

Fonte: arquivo pessoal do autor.

Perto dali, encontra-se o monumento dedicado a José Inácio Peixoto situado na praça conhecida como "pracinha da Vila Tereza". Porém tanto a praça, quanto o próprio monumento estão em situação de abandono, além disso, circulam pessoas estranhas pelo local, trazendo insegurança para os visitantes. Mesmo assim a visita vale a pena para apreciar com calma e atenção o painel de azulejos de Cândido Portinari e a escultura de Bruno Giorgi, dos anos 50. O monumento a José Inácio Peixoto foi inaugurado em 1958 e foi uma homenagem dos funcionários da Companhia Industrial Cataguases.

Próximo ao monumento e da Vila Operária, encerro o trajeto argumentando sobre dois pontos da região industrial: O Sindicato dos Trabalhadores de Energia Elétrica e a outra ponte que corta o Rio Pomba, feita em concreto. Essa ponte já tem bem menos importância arquitetônica do que a metálica, porém a movimentação de carros é bem maior nesta. Isso acontece porque na ponte de concreto possuem duas pistas para veículos, enquanto que na Ponte Metálica só passa um carro por vez, o que exige muito mais a atenção dos motoristas. No dia-a-dia, a verdade é que poucos carros passam pela Ponte Metálica, visto que o motorista pode perder um bom tempo do seu dia apenas para atravessá-la. A seguir mostro uma imagem tirada de cima da ponte de concreto, sendo possível visualizar grande parte do Rio Pomba, a Ponte Metálica do outro lado e parte do Clube do Remo. É importante ressaltar também que na ponte de concreto há uma calçada para pedestres e outra para bicicletas. 
Imagem 19 - Ponte de Concreto com vista para a Ponte Metálica.

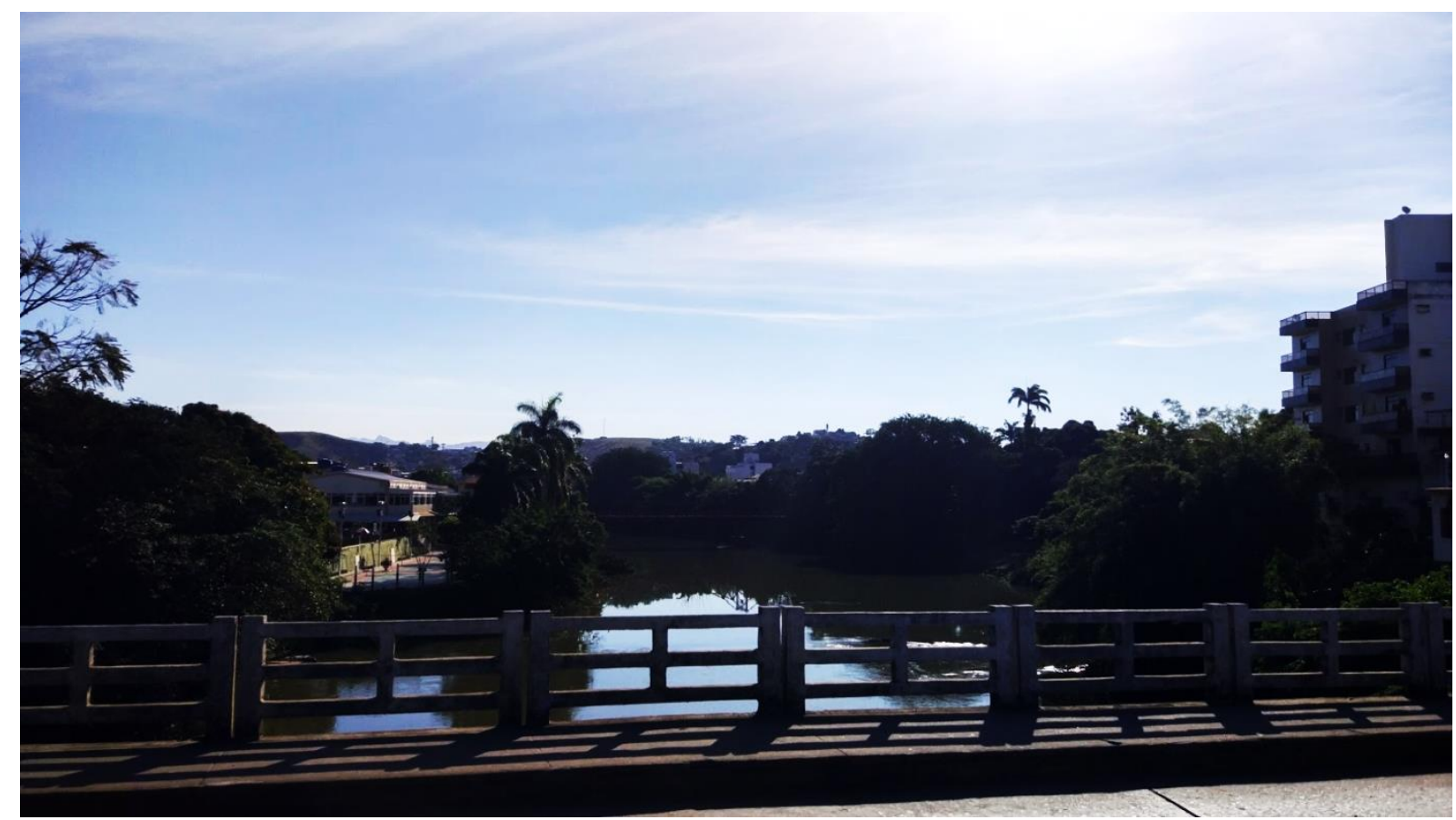

Fonte: arquivo pessoal do autor.

Já o Sindicato dos Trabalhadores de Energia Elétrica tem características muito modernistas, representando bem a arquitetura moderna de Cataguases. Fundado em 1958, atualmente o Sindicato não tem a função de sindicato, e é apenas um edifício tombado, que inclusive é fechado para o público. Recentemente em 2016, o Sindicato recebeu um novo letreiro identificando o edifício. Não há mais tantos trabalhadores/engenheiros/eletricistas para que o sindicato permanecesse em funcionamento. $\mathrm{O}$ interesse nesse ponto é perceber que grande parte dos edifícios e prédios que foram tombados na cidade de Cataguases está abandonada, sem função alguma, o que acaba por não valorizar o turismo da cidade. $\mathrm{Na}$ imagem a seguir podemos visualizar uma imagem que consegui tirar do lado de fora, atravessando a câmera depois da grade que rodeia o edifício. Vale atentar pela marquise da entrada, que possui laje e pilares inclinados, além de grandes planos de vidros, configurando como as principais características modernistas do edifício. 
Imagem 20 - Sindicato dos Trabalhadores da Indústria de Energia Elétrica de Cataguases.

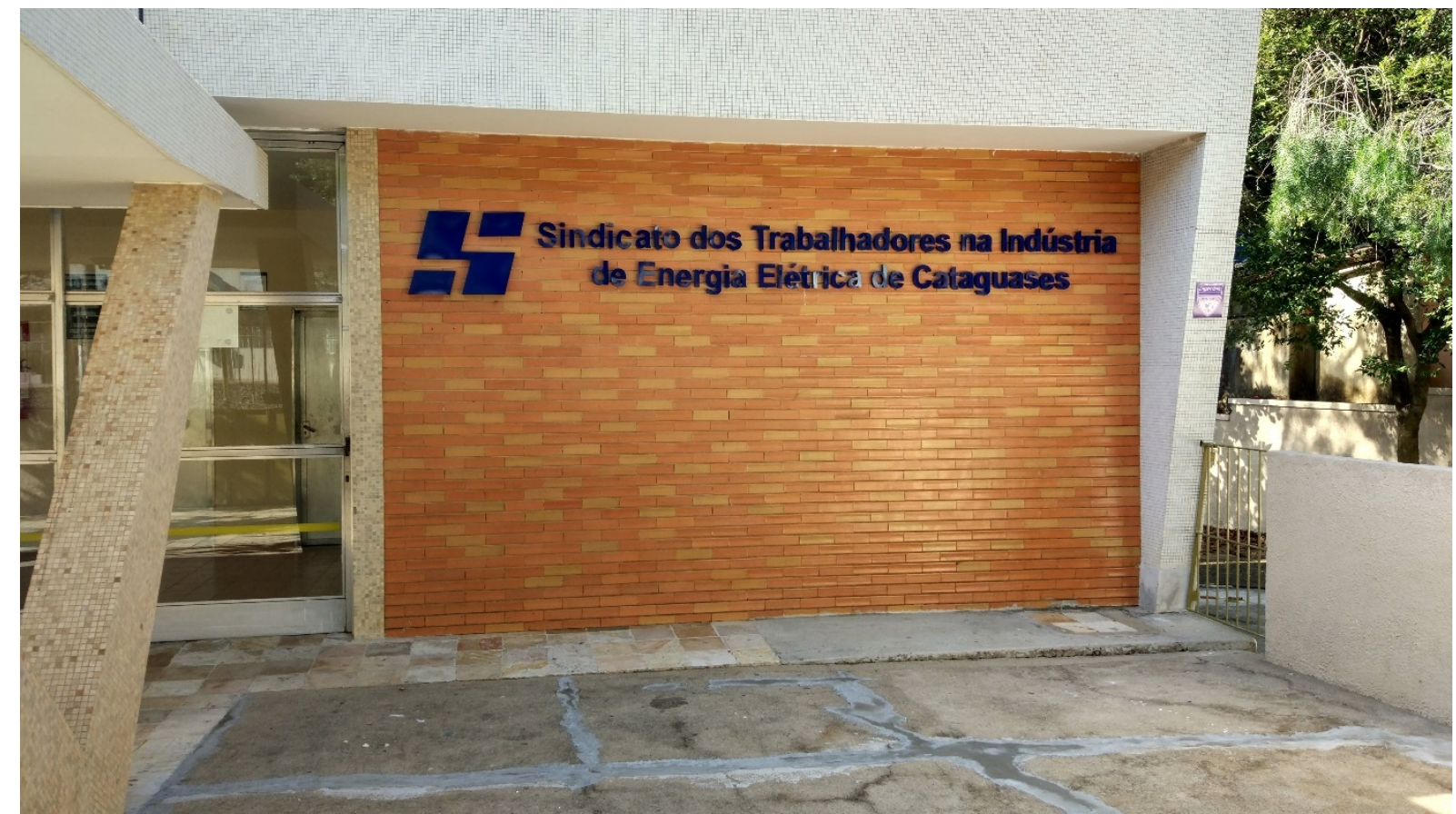

Fonte: arquivo pessoal do autor.

\subsection{Centro de Cataguases}

Agora, nosso trajeto passa para o centro da cidade, onde comtempla a maior parte da beleza colonial de Cataguases. Importantes hotéis, shopping, escolas, feiras, pequenas praças e a maioria dos comércios se concentram no centro da cidade. $\mathrm{O}$ principal acesso para o centro da cidade, passando pela Praça Rui Barbosa, é a Rua Coronel João Duarte que se destaca por um grande movimento de pessoas.

Esta rua se assemelha muito às ruas da cidade de Lisboa em Portugal, não só pela arquitetura colonial dos edifícios, mas também pelos postes de iluminação e bancos de praça ali existentes, e até mesmo pelos nomes de determinados comércios intitulados como "Drogaria Coimbra" ou "Panificadora Lisboa". O movimento por aqui é totalmente diurno, pois às 19 horas os comércios já estão totalmente fechados, dando espaço para os comércios do centro. Como é a principal passagem de pedestres para o centro, os comerciantes aproveitam bastante na pechincha para as vendas, formando quase que uma feira em determinadas horas do dia. Particularmente a cidade é beneficiada por esse trajeto, economicamente mais ainda. Porém a noite torna-se um lugar duvidoso e tomado por pessoas bêbadas e moradores de rua. Vale lembrar que a entrada de carros nessa rua é proibida, assim 
como boa parte das ruas do centro histórico de Cataguases. Na próxima imagem apresento a entrada da Rua Coronel João Duarte.

Imagem 21 - Rua Coronel João Duarte.

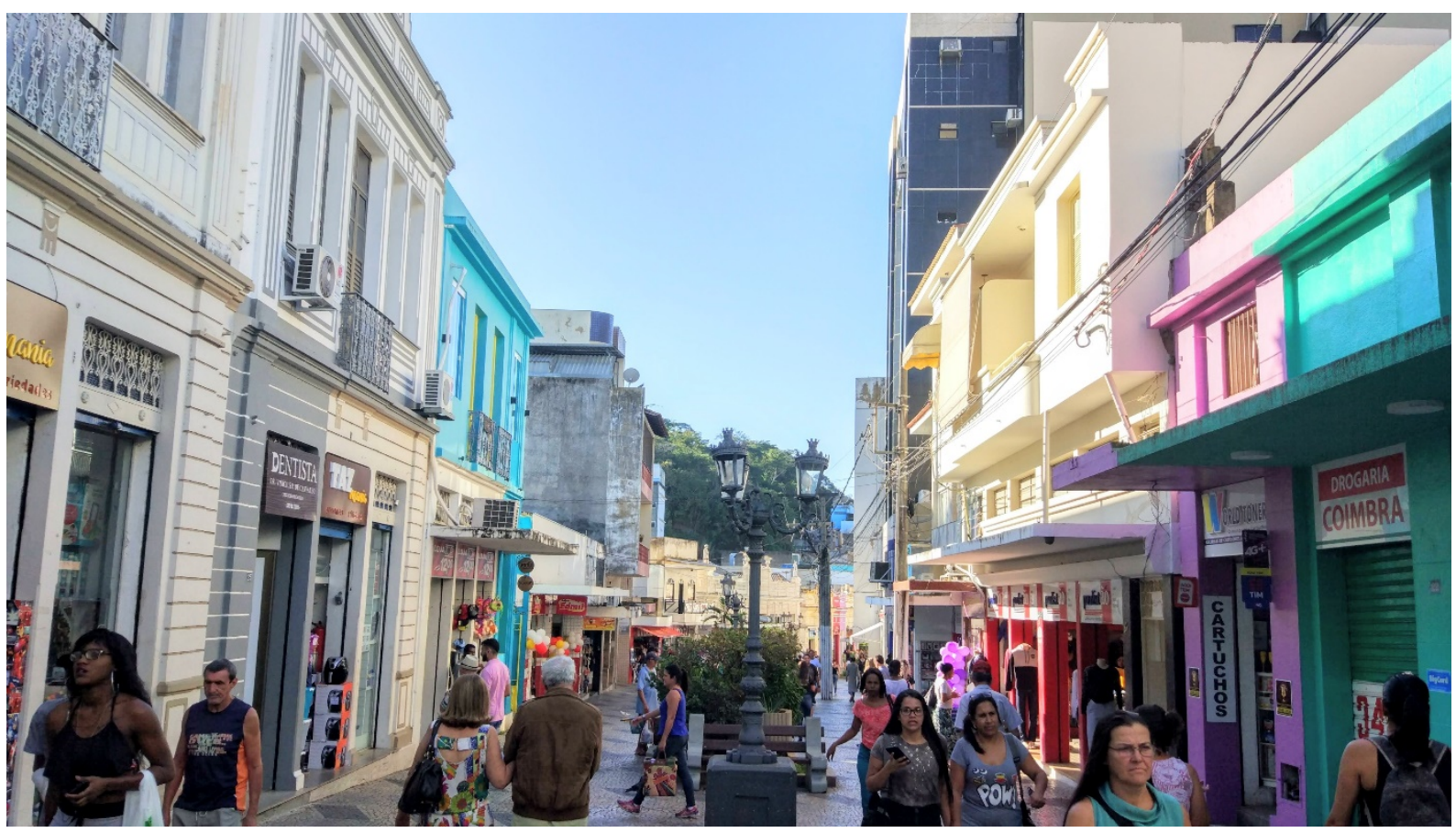

Fonte: arquivo pessoal do autor.

Na Rua Coronel João Duarte podemos ainda perceber edifícios de diversos estilos diferentes em relação à arquitetura. Edifícios inacabados e obras complexas e contemporâneas também fazem parte da composição dessa região central. E isso que é o mais impressionante na cidade de Cataguases, a mistura entre o antigo e o moderno, edifícios tombados com muita história e que atualmente levam uma função especifica para a comunidade, assim como foram no passado, podendo preservar sua história.

Ao sair da rua de entrada do centro, a Coronel João Duarte, somos contemplados com a vista de prédios com diversos tipos de estrutura, e de cara o que mais chama atenção é a estação ferroviária de Cataguases, construída ainda quando Cataguases era escrito: “Cataguazes", com a letra Z, em vez de S. É nessa região que percebemos a importância de conservação do Patrimônio Histórico em uma cidade, como em Cataguases. Nós, que somos de outra cidade, comtemplamos e ficamos imaginando como era na época em que os cariocas vinham até Minas Gerais de trem para realizar seus negócios, deixando suas famílias por dias para trabalhar em outro estado. Graças a isso, Cataguases se tornou um local de destaque, já 
que nomes importantes do Brasil vieram à cidade, trazendo consigo grandes artistas e suas obras, como a de Portinari por exemplo.

$\mathrm{Na}$ imagem a seguir, mostro uma das primeiras vistas do centro, admirando os diferentes tipos de arquitetura existentes.

Imagem 22 - Vista do centro da cidade de Cataguases.

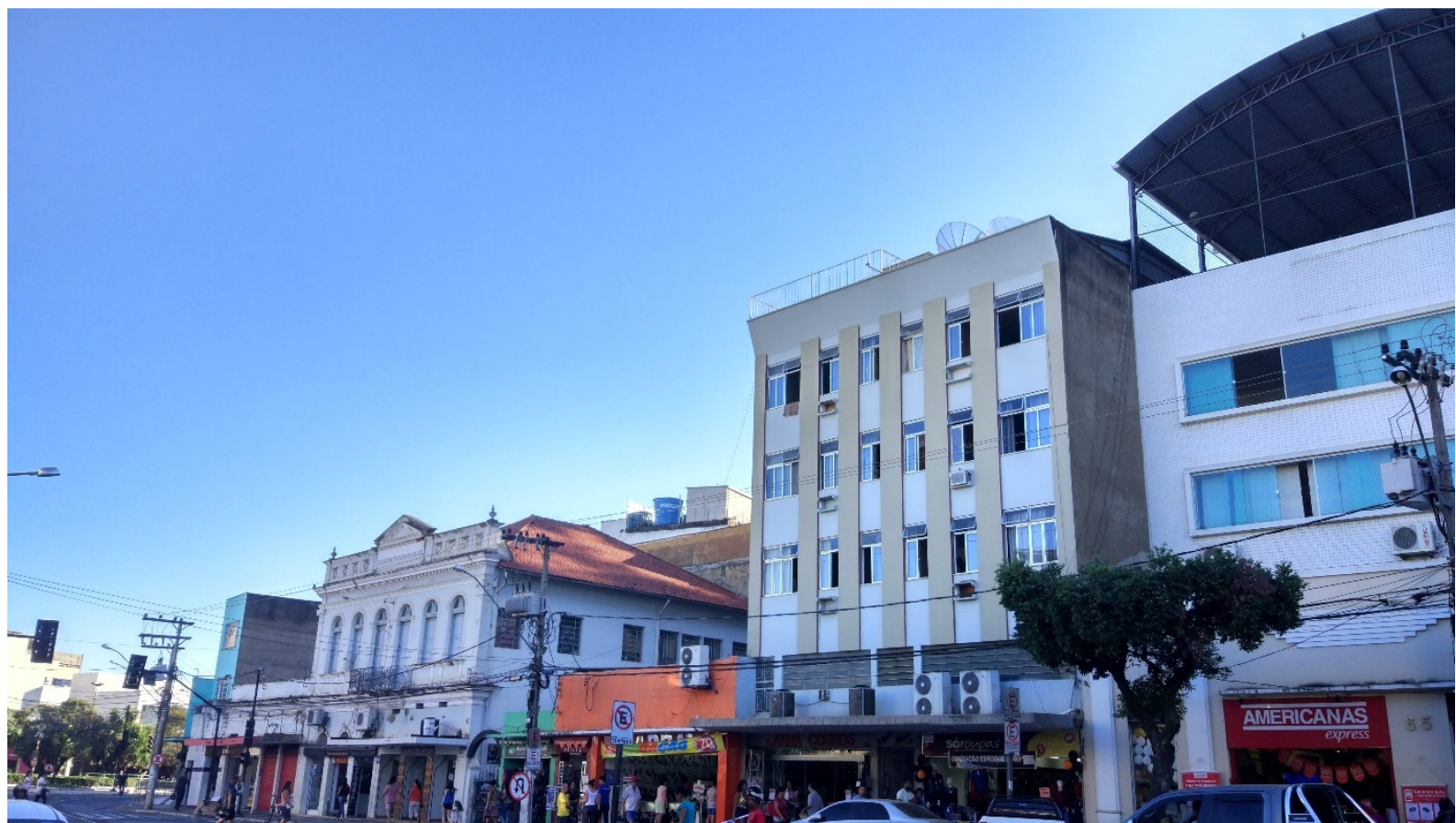

Fonte: arquivo pessoal do autor.

Umas das principais atrações do Patrimônio Cultural de Cataguases é a Biblioteca Municipal Ascânio Lopes, a qual já recebeu grandes nomes literários, além de possuir um acervo bem interessante e grande, com cerca de 25 mil exemplares. Cheia de livros com variados temas, a biblioteca é um espaço harmonioso para ler, tomar um café e realizar outras atividades como participar de oficinas e atrações literárias com agenda programada pela prefeitura local. A Biblioteca é tombada como Patrimônio Cultural da cidade por ser um espaço estratégico de cultura para a comunidade.

No ano de 2018 a Biblioteca Municipal Ascânio Lopes completou 117 anos. Sua localização é na chácara Dona Catarina, que é uma área pública, cedida pela própria Dona Catarina. Ocupando um dos espaços públicos mais valorizados e democráticos da cidade, é frequentada em maior número por estudantes e professores, recebendo aproximadamente 100 visitantes por dia para pesquisa em obras das literaturas nacional e também estrangeira, de acordo com a bibliotecária do local. Na imagem a seguir é possível visualizar a biblioteca e ao 
fundo vários edifícios de característica mais moderna, construídos com o crescimento da cidade.

Imagem 23 - Biblioteca Municipal de Cataguases Ascânio Lopes.

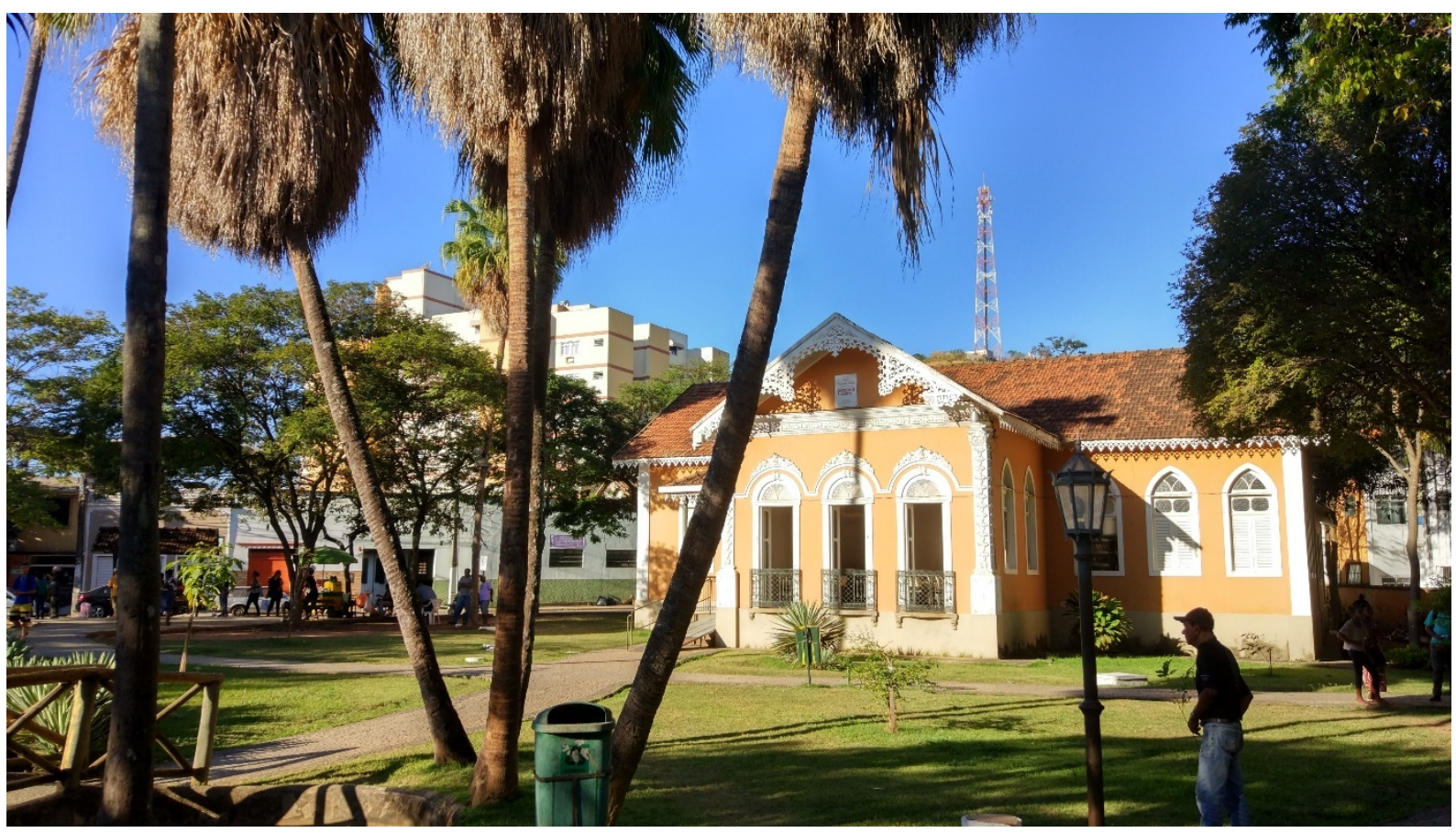

Fonte: arquivo pessoal do autor.

A partir desse ponto, vemos ao lado da biblioteca, a Estação Ferroviária, que foi percurso de ida e vinda de muitos trens para outras cidades de Minas Gerais e do Rio de Janeiro. Atualmente a Estação Ferroviária abriga o Arquivo Central de Documentos da Prefeitura de Cataguases, no qual fui bem recebida para argumentar vários pontos desta pesquisa e a sede do Instituto do Patrimônio Histórico e Artístico Nacional, o IPHAN, no qual tivemos acesso a muitas informações com o servidor que me atendeu prontamente. Esses dois locais são o berço da pesquisa histórica de Cataguases, com jornais, plantas baixas, filmes, documentos, cartas, fotografias etc. que contam praticamente toda a história de Cataguases, em seus diversos períodos históricos.

Na Estação Ferroviária há também um espaço para os artistas exporem suas obras. Porém nos dias da pesquisa de campo o local estava fechado e ao perguntar o motivo para a funcionária do Arquivo Central, ela informou que a Prefeitura tinha fechado o espaço nesse ano de 2018. 
Imagem 24 - Estação Ferroviária de Cataguases.

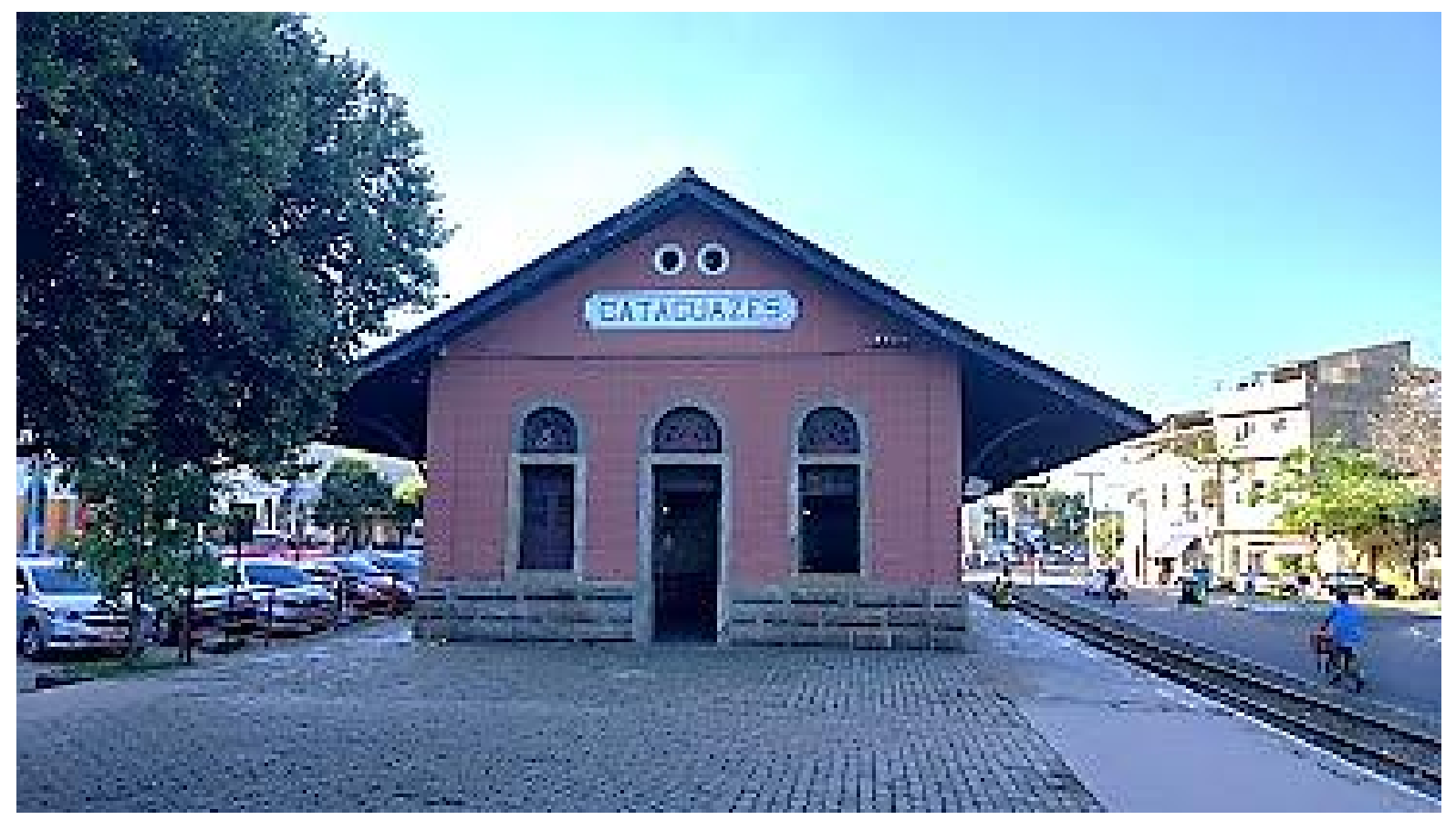

Fonte: arquivo pessoal do autor.

Por questão de curiosidade, é interessante quando chegar à sede do IPHAN e se deparar com fotos de cada momento histórico da cidade. E é aí que se percebe o gratificante trabalho do IPHAN em preservar a memória da cidade de Cataguases e por quantos momentos históricos e culturais a cidade passou. A imagem pode ser conferida a seguir, onde os quadros estão representados por ordem histórica de maneira crescente. 
Imagem 25 - Quadros localizados na entrada da sede do IPHAN em Cataguases.

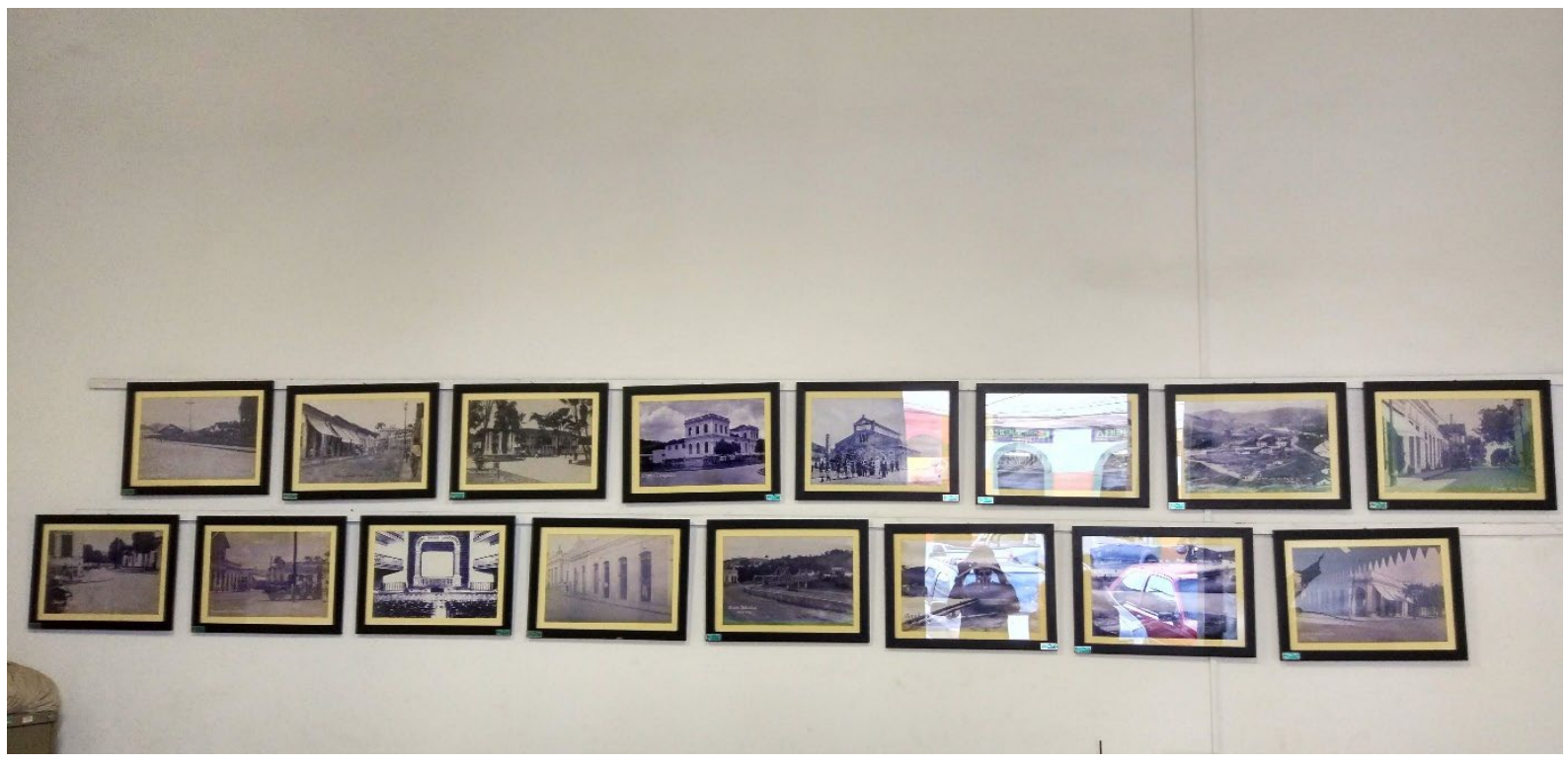

Fonte: arquivo pessoal do autor.

Após sair da sede do IPHAN, podemos visualizar mais dois pontos importantes de Cataguases: o Grande Hotel Villas e a Antiga Fábrica de Fiação e Tecelagem. Ambos os edifícios são tombados pelo IPHAN. O Grande Hotel Villas continua funcionando como hotel e recebe periodicamente uma manutenção da Prefeitura em sua área interna e externa para a preservação do Patrimônio Histórico e Material. Este hotel é um exemplo bem comum do que ocorre em outras cidades brasileiras: funcionar como hotel ao mesmo tempo em que conta a história da cidade.

Um exemplo que se assemelha ao Grande Hotel Villas, é o que acontece em Pirenópolis, no estado de Goiás. Lá também se encontram muitos edifícios tombados como Patrimônio Histórico que não perderam sua essência e continuam em funcionamento até hoje. Exemplo disso é o hotel Casarão, localizado bem no centro da cidade. É um edifício tombado pelo IPHAN que foi parte do Período Imperial do Brasil. Apresento uma foto do seu interior, já que pude conhecê-lo logo no final de 2018. 
Imagem 26 - Interior do Hotel Casarão em Pirenópolis-GO.

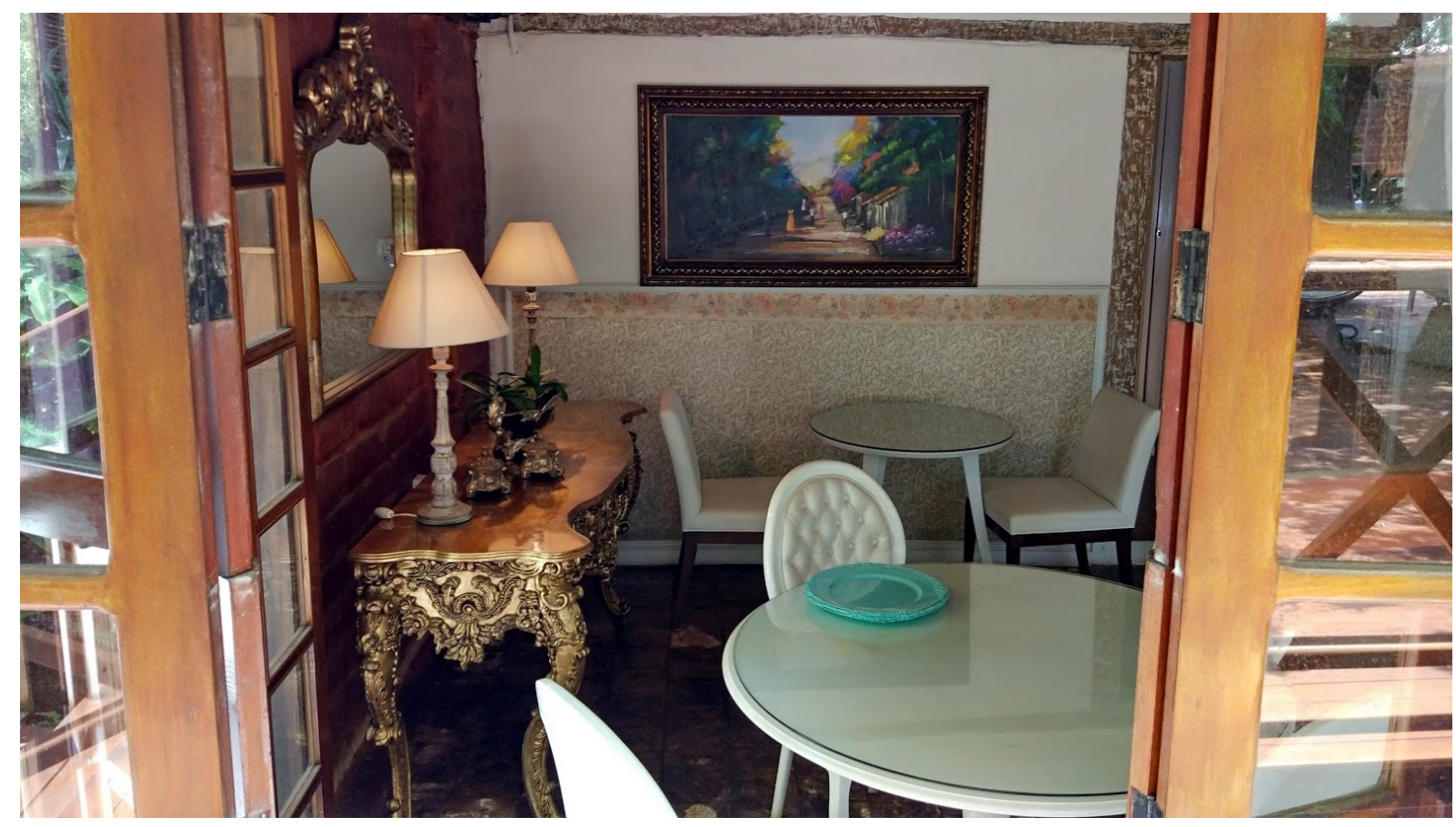

Fonte: arquivo pessoal do autor.

O Grande Hotel Villas, de estilo colonial, foi projetado por Guido Bergamini em 1893 para ser sede da matriz do Banco de Cataguases. O projeto foi encomenda do português João Duarte Ferreira, que comerciava café na região. Já no ano de 1895 o prédio foi arrendado por José Villas Bouçada que o transformou no que ele é hoje. Na imagem abaixo vemos uma imagem do hotel. 
Imagem 27 - Fachada do Grande Hotel Villas.

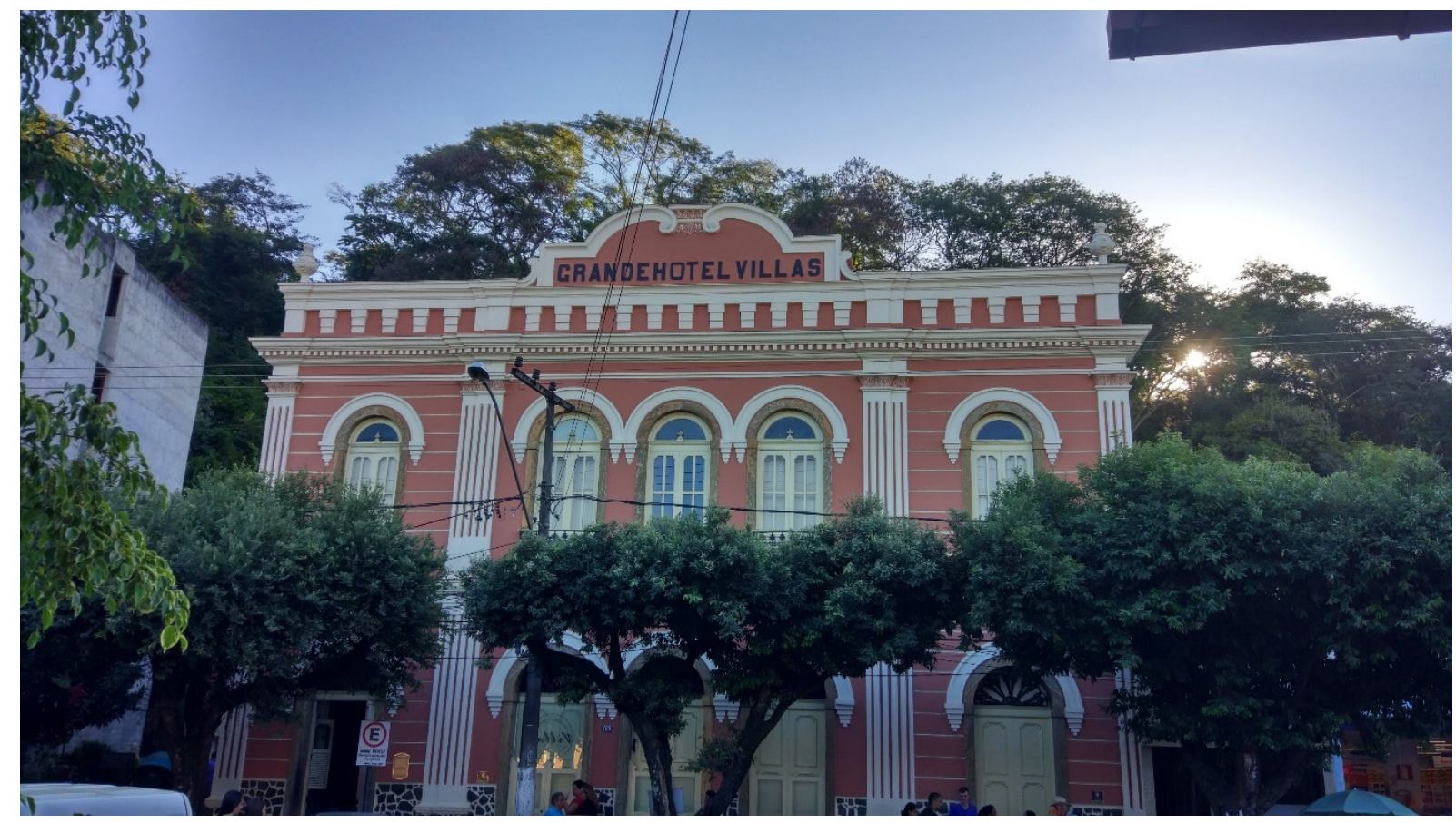

Fonte: arquivo pessoal do autor.

Já a Antiga Fábrica de Fiação e Tecelagem, hoje atua como o Shopping Bahamas, a fachada e toda a estrutura externa do edifício são conservadas, por se tratar de um edifício tombado pelo IPHAN. A Antiga Fábrica de Tecelagem, junto com a indústria têxtil nasce em Cataguases em 1905 com a criação da Companhia de Fiação e Tecelagem Cataguases.

Em 1910, em virtude de problemas conjunturais, a empresa entra em grandes dificuldades e fica inativa. No ano seguinte, é adquirida por Manoel Inácio Peixoto, um português natural da ilha do Pico, arquipélago dos Açores, que se estabeleceu em Cataguases como comerciante quando nessa cidade chegou com a construção da estrada de ferro Leopoldina. Com a mudança de controle acionário, muda, também, a denominação da sociedade, passando a se chamar "Manoel Inácio Peixoto" (CATAGUASES, 2019).

Hoje a Companhia Industrial atua na região Industrial de Cataguases desde 2013.

Atualmente, o Shopping Bahamas possui uma mescla de informações e uma estrutura tanto antiga, conservada, como também moderna. O Shopping conta com duas salas de cinema, restaurante, supermercado e cerca de cinco lojas de itens variados. As salas de cinema e o supermercado ocupam quase todo o prédio. Pude conferir tanto o cinema como também o supermercado e quando você entra em qualquer um desses dois locais, parece que se está em 
outro ambiente fora da Fábrica de Tecelagem, já que, por dentro, a estrutura do edifício foi toda modernizada.

Imagem 28 - Lateral do Shopping Bahamas, antiga Fábrica de Fiação e Tecelagem.

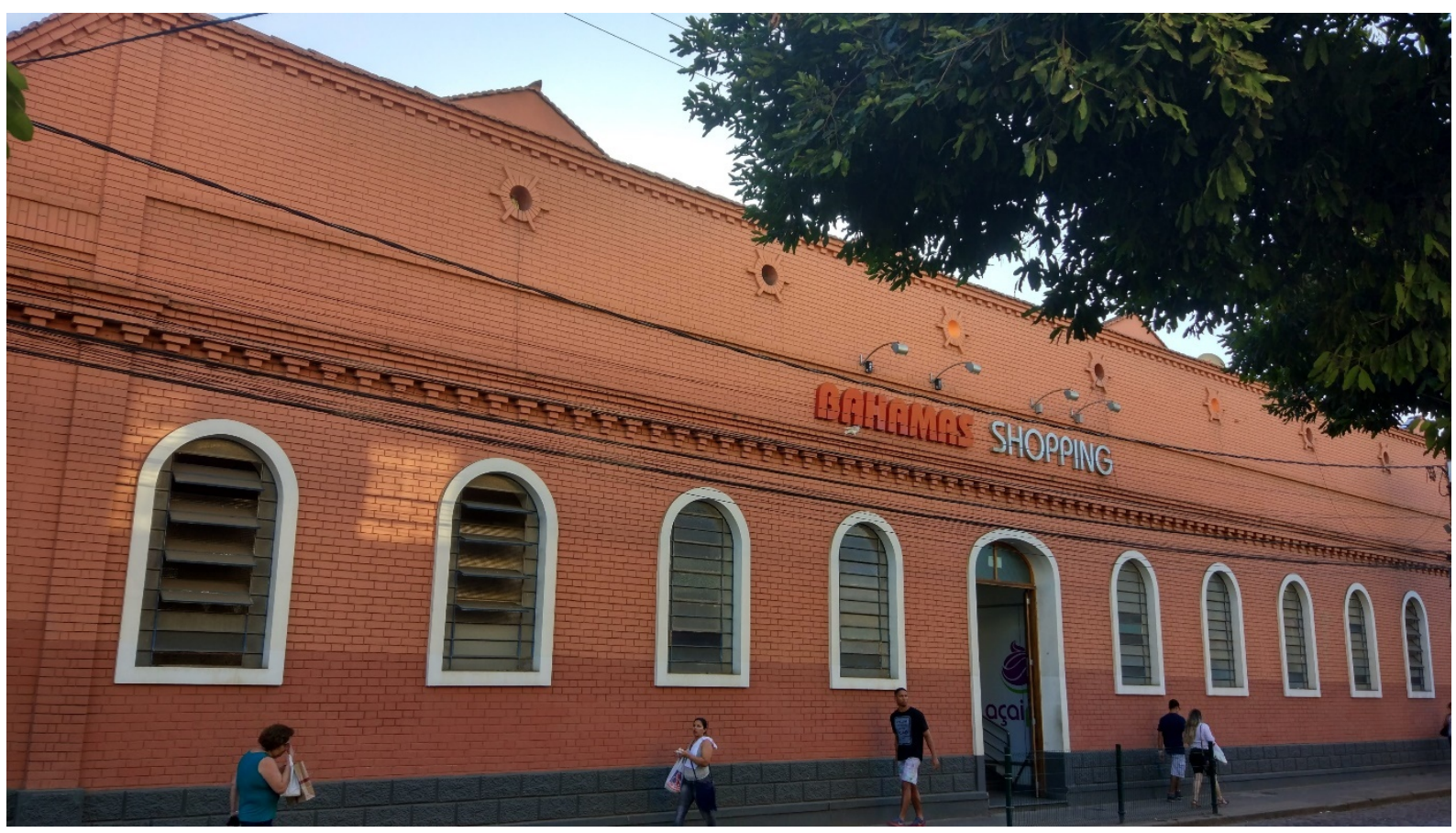

Fonte: arquivo pessoal do autor.

Assim, conclui o trajeto de acordo com toda área que é tombada pelo IPHAN no centro da cidade. Porém irei voltar à região cultural que abriga outro ponto importante: o Hotel Cataguases. Primeiramente é um dos hotéis cinco estrelas da cidade e o mais caro da cidade. A visitação é livre e é, também, aberto para outros eventos como festa de aniversário e casamento (inclusive, no dia da visita de campo estava acontecendo um casamento). O espaço conta com obras artísticas e esculturais de artistas renomados, além de uma arquitetura moderna perplexa. É um dos lugares tombados pelo IPHAN mais bem conservados de Cataguases. O edifício foi projetado em 1951 pelos arquitetos Aldary Henriques Toledo e Gilberto Lyra de Lemos.

Aos arredores do hotel, existem jardins generosos com um espelho d'água e uma escultura de Jan Zack. Em seu interior, o saguão principal está sobre pilotis e possui amplas portas de correr em vidro, o bar é coberto por laje plana sobre pilares arredondados e também se destaca uma parede em mosaico de ladrilhos hidráulicos. Na imagem a seguir fotografei o hall de entrada do hotel, ornamentado com dois quadros de Portinari em suas paredes. 
Imagem 29 - Hall do Hotel Cataguases.

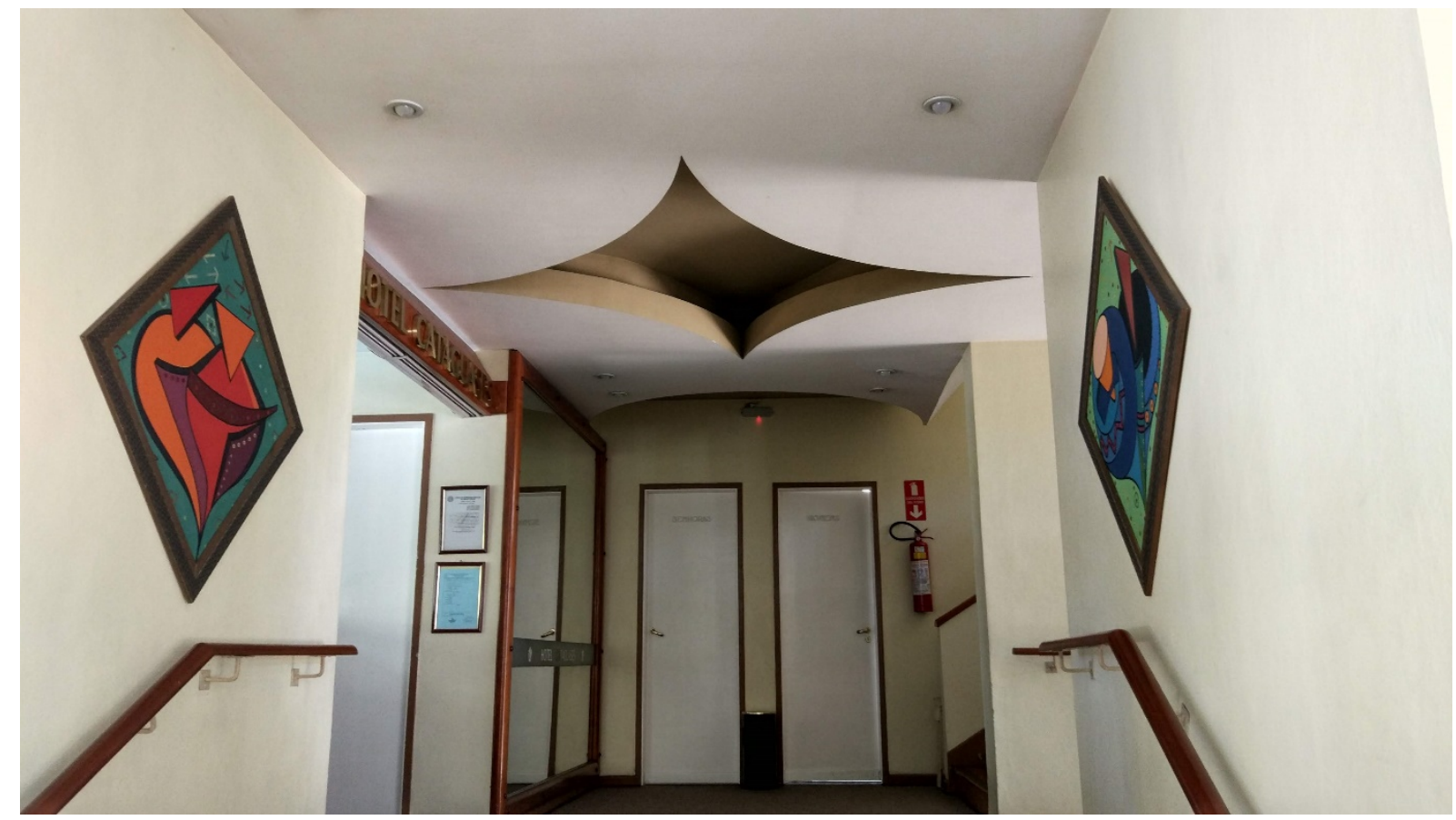

Fonte: arquivo pessoal do autor.

A visita a esse hotel fechou a viagem com "chave de ouro", pois foi encontrado meio que por acaso ao longo dos trajetos pela cidade. É um edifício de valor arquitetônico e artístico muito valioso, a sua visitação valeu muito a pena. 


\section{CONSIDERAÇÕES FINAIS}

Ao longo da pesquisa, o que mais percebi é que o maior desafio para a conservação do Patrimônio Histórico, Material e Cultural é a própria manutenção do espaço, e sua aprovação pela comunidade local da cidade. A cidade de Cataguases vive um histórico de patrimônio de sucesso com obras arquitetônicas que só em algumas cidades do Brasil é possível encontrar. Como arquiteta sempre me deslumbrei por obras arquitetônicas modernas, enquanto que as coloniais fazem parte de toda uma história de estrutura de formação da cidade como identidade. Porém, acredito que quem faz da cidade uma cidade são os próprios habitantes locais, e como eles usam essa estrutura arquitetônica para o convívio social, lazer, educação, saúde, comércio etc.

É interessante notar que, apesar de ser uma cidade do interior brasileiro, com cerca de apenas vinte mil habitantes naquela época, nos anos de 1950, a arquitetura modernista em Cataguases se desenvolveu quase que simultaneamente a dos grandes centros urbanos do país como, por exemplo, a construção do conjunto da Pampulha, em Belo Horizonte. Percebe-se nessa cidade que os arquitetos brasileiros tiveram a oportunidade de colocar em prática suas ideias e seus conhecimentos, além de renovar os padrões culturais e estéticos. Neste sentido, também estão os jardins projetados, que complementam tanto edifícios particulares como públicos.

Assim, claramente senti ao adentrar em Cataguases, que a cidade viveu seus momentos como em uma vida, seguindo tendências, ambições, guerras, amizades e acima de tudo a conservação e a arte. Considero a arquitetura como uma arte, e a preservação da arquitetura sempre foi e será um desafio. Pensar no Patrimônio Histórico de uma cidade acima de tudo é viver o momento da cidade. E foi isso que decidi fazer nesta pesquisa, pela qual tive oportunidade de conhecer mais uma cidade histórica do Brasil, e ainda mais, poder argumentar um pouco mais sobre ela para várias pessoas, principalmente na área de Patrimônio Histórico e Artes.

No final, todo o planejamento, como explicado no início do trabalho foi realizado pelo Google Maps, no qual deixei público para quem quiser acessar o mapa intitulado "Pesquisa Cataguases". Abaixo apresento uma imagem com o planejamento final de toda pesquisa. 
Imagem 30 - Planejamento Final do trajeto da pesquisa em Cataguases.

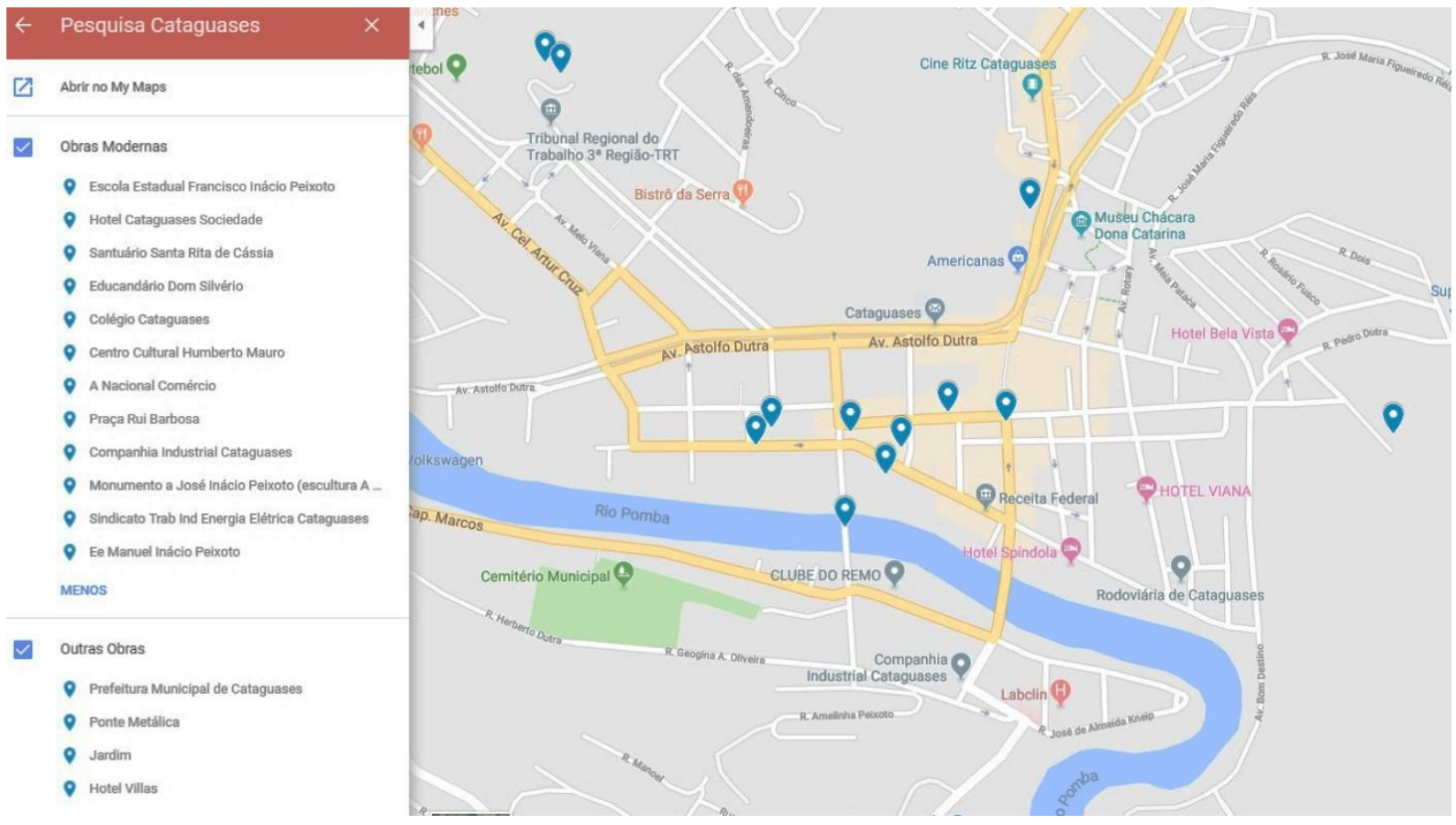

Fonte: Google Maps.

Em resumo, Cataguases é realmente a mistura da arquitetura antiga e moderna, e que, em cada passo, em cada rua, é uma história ali que está sendo contada pela própria cidade, graças à conservação dos edifícios arquitetônicos, a cultura ativa e as lutas históricas que a cidade enfrentou. Um resumo bem claro de como é andar em Cataguases está representado nessas duas imagens a seguir: uma representa a arquitetura moderna e outra a arquitetura colonial, ambas localizadas na mesma rua. 
Imagem 31 - Arquitetura Moderna de Cataguases.

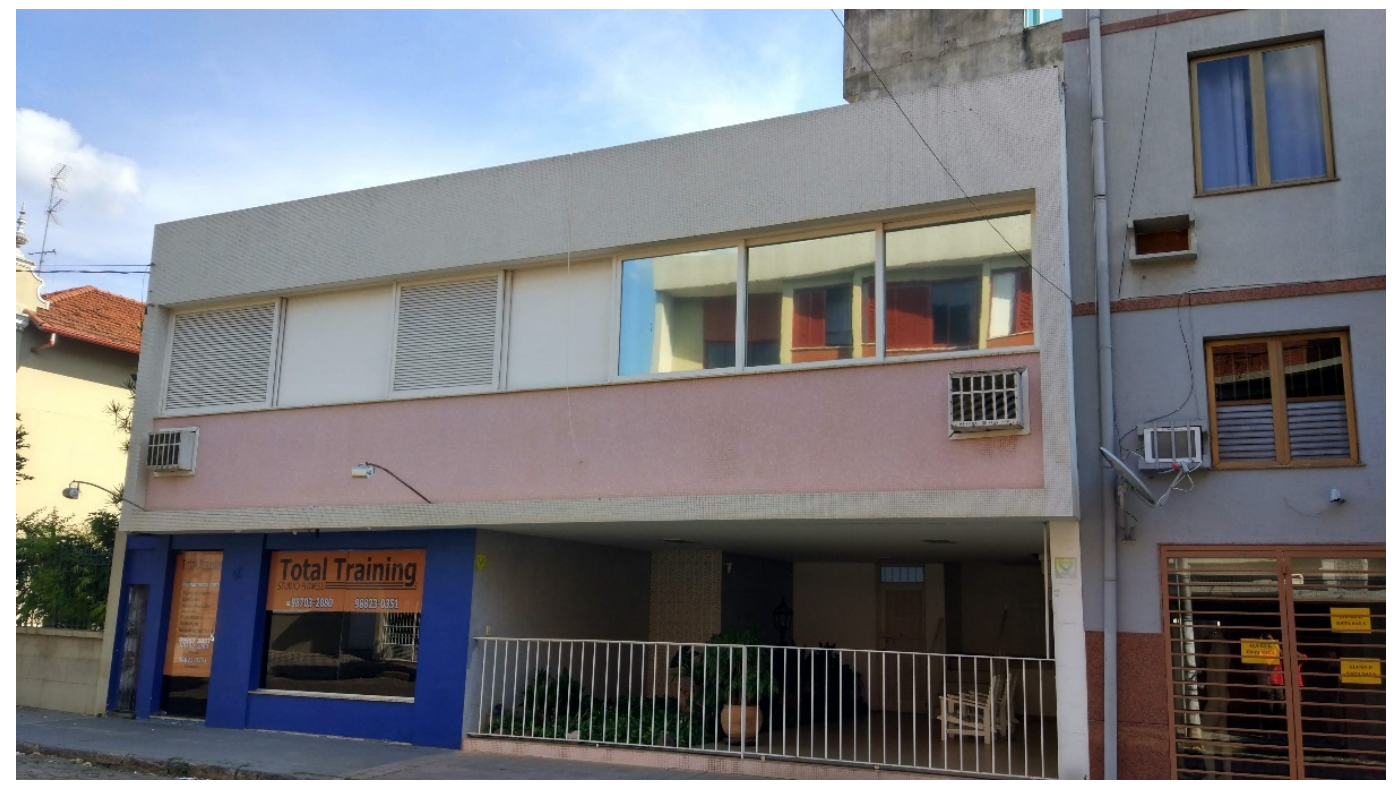

Fonte: arquivo pessoal do autor.

Imagem 32 - Arquitetura Colonial de Cataguases.

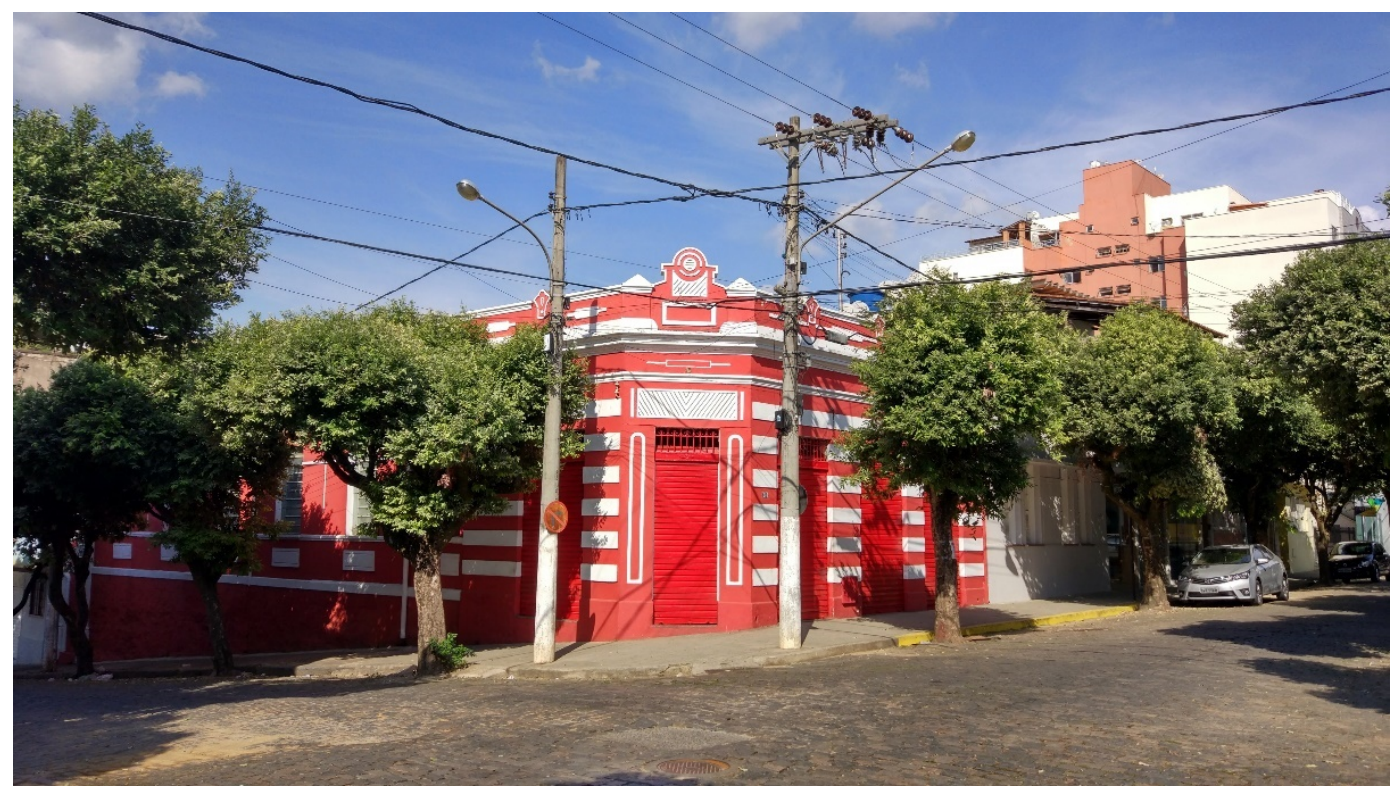

Fonte: arquivo pessoal do autor. 


\section{REFERÊNCIAS}

ALONSO, Paulo Henrique. Guia da arquitetura modernista de Cataguases - 2 ed. Cataguases / MG: Instituto Cidade de Cataguases, 2012.

BRASIL, Constituição da República do Brasil, de 05 de outubro de 1988. Senado Federal, Brasília, DF, 05 de outubro de 1988.

CATAGUASES. Site da Companhia Industrial de Cataguases. História. Acesso em: www.cataguases.com.br. Acessado em 02 de janeiro de 2019.

FUNARI, Pedro Paulo; PINSKY, Jaime. Turismo e patrimônio cultural. 3a ed. São Paulo: Contexto, 2003.

GIL. A, C. Como elaborar projetos e pesquisa. $3^{\text {a }}$ edição. São Paulo: Atlas; 1995.

INSTITUTO BRASILEIRO DE GEOGRAFIA E ESTATÍSTICA. Ministério do Planejamento, Orçamento e Gestão. 2009. Disponível em: $<$ http://www.ibge.gov .br/cidadesat/topwindow.htm?>.

INSTITUTO DO PATRIMÔNIO HISTÓRICO E ARTISTICO NACIONAL, Ministério da Cultura. Processo no. 1342-T-94, Processo de Tombamento de Cataguases-MG, conjunto histórico, arquitetônico e paisagístico, Belo Horizonte, MG, 1994.

SANTOS, Cecília Rodrigues dos; LAGE, Cláudia Freire. Cataguases: patrimônio da modernidade, janeiro, 2005.

VALLE, Edgar Guimarães do. Projeto da Matriz de Cataguases. [S.1 ., 19--]. Prancha com planta baixa. Consultado no Arquivo Público de Cataguases. Reformulação do Arquivo em 1996. 